Portland State University

PDXScholar

\title{
A Brief Portrait of Multimodal Transportation Planning in Oregon and the Path to Achieving It, 1890-1974
}

Carl Abbott

Portland State University, d3ca@pdx.edu

Sam Lowry

Portland State University

Follow this and additional works at: https://pdxscholar.library.pdx.edu/usp_fac

Part of the Transportation Commons, Urban Studies Commons, and the Urban Studies and Planning Commons

Let us know how access to this document benefits you.

\section{Citation Details}

Abbott, Carl and Sam Lowry. A Brief Portrait of Multimodal Transportation Planning in Oregon and the Path to Achieving It, 1890-1974. OTREC-TT-10-01. Portland, OR: Transportation Research and Education Center (TREC), 2010. http://dx.doi.org/10.15760/trec.133

This Report is brought to you for free and open access. It has been accepted for inclusion in Urban Studies and Planning Faculty Publications and Presentations by an authorized administrator of PDXScholar. Please contact us if we can make this document more accessible: pdxscholar@pdx.edu. 


\section{SOTREC}

FINAL REPORT

\section{A Brief Portrait of Multimodal Transportation Planning in Oregon and the Path to Achieving It, 1890-1974}

OTREC-TT-10-01 January 2010 



\title{
A BRIEF PORTRAIT OF MULTIMODAL TRANSPORTATION PLANNING IN OREGON AND THE PATH TO ACHIEVING IT, 1890-1974
}

\author{
Final Report
}

\section{OTREC-TT-10-01}

by

Sam Lowry, Co-principal Investigator

Portland State University

\section{for}

The Oregon Transportation Research and Education Consortium (OTREC)

P.O. Box 751

Portland, OR 97207

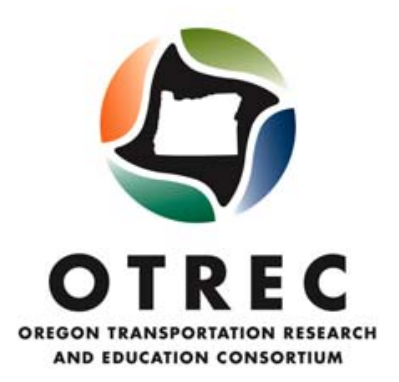

January 2010 



\section{Technical Report Documentation Page}

\begin{tabular}{|c|c|c|}
\hline $\begin{array}{l}\text { 1. Report No. } \\
\text { OTREC-TT-10-01 }\end{array}$ & 2. Government Accession No. & 3. Recipient’s Catalog No. \\
\hline \multicolumn{2}{|c|}{$\begin{array}{l}\text { 4. Title and Subtitle } \\
\text { A Brief Portrait of Multimodal Transportation Planning in Oregon and the Path to Achieving } \\
\text { It, 1890-1974 }\end{array}$} & 6. Performing Organization Code \\
\hline \multicolumn{2}{|c|}{$\begin{array}{l}\text { 7. Author(s) } \\
\text { Carl Abbot, Principal Investigator } \\
\text { Sam Lowry, Co-principal Investigator }\end{array}$} & 8. Performing Organization Report No. \\
\hline \multicolumn{2}{|c|}{ 9. Performing Organization Name and Address } & 10. Work Unit No. (TRAIS) \\
\hline \multicolumn{2}{|c|}{$\begin{array}{l}\text { Sam Lowry, Co-principal Investigator } \\
\text { Portland State University, PO Box 751, Portland, OR 97207-0751 }\end{array}$} & $\begin{array}{l}\text { 11. Contract or Grant No. } \\
\text { 2008-D-14 }\end{array}$ \\
\hline \multirow{2}{*}{\multicolumn{2}{|c|}{$\begin{array}{l}\text { 12. Sponsoring Agency Name and Address } \\
\text { Oregon Transportation Research and Education Consortium (OTREC) } \\
\text { P.O. Box 751, Portland, Oregon } 97207\end{array}$}} & $\begin{array}{l}\text { 13. Type of Report and Period Covered } \\
\text { Final Report, 10/1/07-9/30/09 }\end{array}$ \\
\hline & & 14. Sponsoring Agency Code \\
\hline
\end{tabular}

15. Supplementary Notes

\section{Abstract}

Excerpts:

"With its statewide land use program, urban growth boundaries, Transportation Planning Rule (TPR), active (often activist) citizenry, progressivedominated government, and, in Portland, modern history of transit investment and self-consciously alternative urban self-concept, Oregon has gone further, for longer, and been more successful than most places in pushing back against automobiles' dominance of environment, lifestyle, and landscape.

"Two moments in time brought particular change. In shifting away from freeway-building in the 1970s, Portland-area and state planners decided that transportation decisions and infrastructure need no longer dictate land use but could serve it. And with the 1991 TPR, Oregon became a pioneer in managing what has been called the transportation land-use connection.

“The story of Oregon's 'multimodal' transportation planning must be written in such as way as to inform [the] commuter ... about the system he thinks just is, how it got there, and how and why he should appreciate its substance. As much as possible, the story, as it is begun here, relates complex subject matter to his life and times, delving into the big controversies that come from society's deep disagreement over conservation and development, aesthetics and wealth. It dips into older history, then moves more or less chronologically. In order to do justice to the various practitioners and players, it includes four stages of action: the national, the metropolitan, the state governmental and the local.”

"A full history to the present day would also attend to some of the less attended-to aspects of transportation planning, the ones that do not as often appear on newspapers' front pages. These include freight planning and its relationship to the business and corporate communities; the specialized work of modelers, system-design technologists, economists, and intelligent-transportation engineers; and the visions, dreams, schemes and projections of futurists, whose imaginings in bygone eras truly led to the very infrastructures we see today. Some current visions - from hydrogen highways to cycle-towns, bullet trains to electric-car cities, biofueled states to right-priced thoroughfares - will become the daily environments of tomorrow, while other visions fade away."

\section{Key Words}

Transportation, planning, Oregon, history, multimodal, land use

18. Distribution Statement

No restrictions. Copies available from OTREC: www.otrec.us
19. Security Classification (of this report)

Unclassified

20. Security Classification (of this page)
Unclassified

21. No. of Pages
72




\section{ACKNOWLEDGEMENTS}

The author thanks OTREC for its support, OTREC staff for their help and patience, interviewees for their trust and stories, and reviewers unknown for helping create the opportunity. Special thanks to Carl Abbott, Mike Burton, Andy Cotugno, Craig Greenleaf and Ed Sullivan for confidence in the endeavor, and to Bob Cortright and Mark Greenfield for extra time and patience. Thanks to John Lynch and Dan Richardson for sharing enthusiasm. Above all thanks to Elaine Lowry for forbearance.

\section{DISCLAIMER}

The contents of this report reflect the views of the author, who is solely responsible for the facts and the accuracy of the material and information presented herein. This document is disseminated under the sponsorship of OTREC the U.S. Department of Transportation University Transportation Centers Program in the interest of information exchange. The U.S. Government assumes no liability for the contents or use thereof. The contents do not necessarily reflect the official views of OTREC or the U.S. Government, Portland State University. This report does not constitute a standard, specification, or regulation. 


\section{TABLE OF CONTENTS}

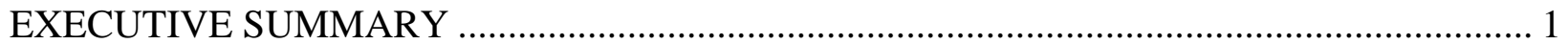

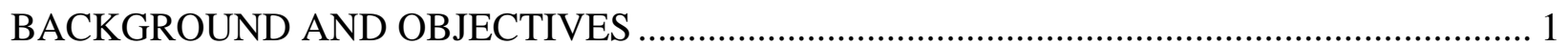

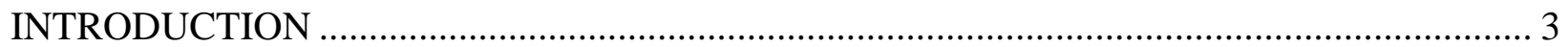

1.0 ANOTHER QUIET YEAR IN THE TRANSPORTATION NEWS ................................ 7

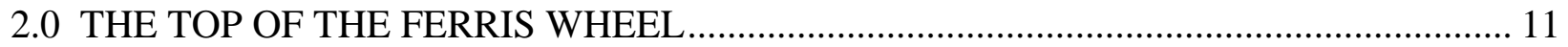

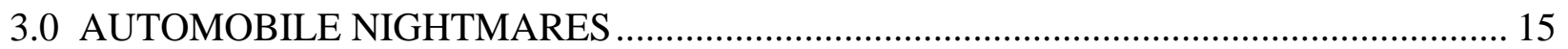

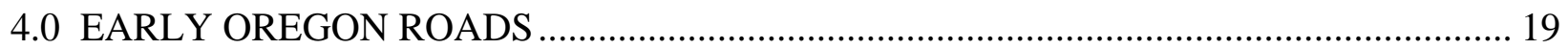

5.0 PETROLEUM, THE VHS OF AUTO FUELS ............................................................ 21

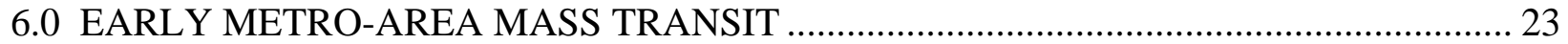

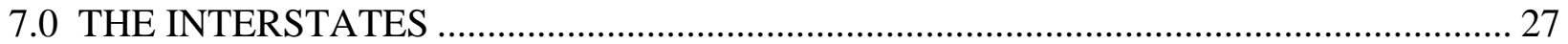

8.0 OREGON'S INTERSTATES AND “GENERAL” GLENN JACKSON .......................... 31

9.0 1950S WORRIES \& THE DAWN OF ENVIRONMENTALISM ..................................... 35

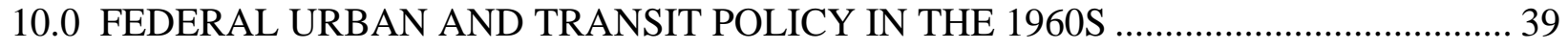

11.0 RCT, MPC, CRAG, PVMTS, Tri-Met, MSD, Metro, JPACT! ........................................ 41

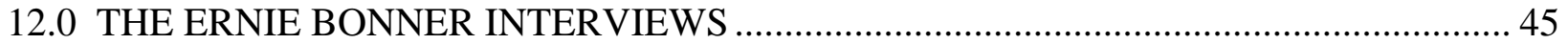

13.0 DOWNTOWN REVITALIZATION AND HARBOR DRIVE .................................... 47

14.0 NEIL GOLDSCHMIDT, THE GOVERNOR'S TASK FORCE, AND THE MT. HOOD

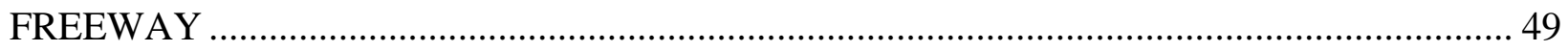

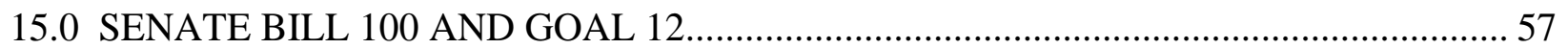

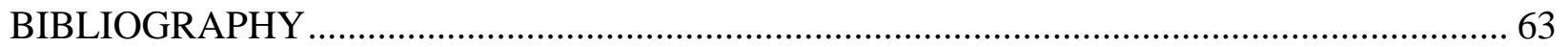




\section{EXECUTIVE SUMMARY}

This project was designed to outline transportation chapters of a planned written history of Oregon land use planning, written in ways that would make the transportation planning profession relevant to a popular audience. The writing would focus on stories from the profession, and on historical facts and events in Oregon transportation planning history that would surprise or enlighten popular reading audiences. Technology transfer would occur through publication of one or more written pieces of work.

The result is a topical and historical tale entitled "A Brief Portrait of Multimodal Transportation Planning in Oregon and the Path to Achieving It, 1890-1974.”

Sources told stories with enthusiastic reference to past transportation events. The structure chosen was an interwoven collection of topical essays, arranged chronologically but skipping sideways, sometimes backward or forward, from stage to stage - national, metropolitan, state governmental, local - but always moving forward in time. The tale presented here takes the reader through tumultuous early years, up to the moment in 1974 when statewide planning goals, including Goal 12, the transportation goal, were adopted by the Oregon Legislature.

\section{BACKGROUND AND OBJECTIVES}

The intent of this project, as presented to OTREC reviewers in early 2007, was to ensure attention to the transportation component of a planned popular history of land use planning in Oregon, and to tell stories from the transportation planning profession that would make the profession relevant to a popular audience.

The scope was presented as a "modest historical-journalistic research and writing project," with the following intended work products:

- enumeration of interfaces between transportation and land use planning in Oregon

- timeline of significant events in Oregon transportation planning

- conversations with important past and present players

- discovery and compilation of important information sources

- discussion of current debates about Oregon transportation planning

- one or more pieces of writing and effort at publication

In imagining the sort of content that could emerge from the research process, the author chose to highlight "stories of vision; stories of grinding dedication; stories of tremendous creativity and innovation; stories of conflict," as well as important historical facts and events in Oregon transportation planning that would be likely to surprise or enlighten popular reading audiences. 


\section{DESCRIPTION OF TECHNOLOGY TRANSFER ACTIVITY}

As proposed, technology transfer would occur through publication of one or more written pieces of work.

\section{OUTCOME AND RESULTS}

In fulfillment of his grant obligation the author hereby submits the topical and historical tale that begins immediately below, entitled "A Brief Portrait of Multimodal Transportation Planning in Oregon and the Path to Achieving It, 1890-1974.”

The process of engaging and researching the subject matter revealed its complex nature; this was described in a preliminary final report. One writing approach considered at that time - eleven parallel essays on each of eleven facets ("The Planners," "The City," etc.) - was discarded as insufficient. The other approach considered, a single, unified essay, was chosen. In the writing process, the approach expanded organically into a collection of topical essays.

It had been clear early on that an ideal way to structure the material would be chronological. Source after source began the stories they told with enthusiastic reference to a transportation event in the 1920s, 1930s, 1950s, etc. It seemed essential to build up the unfamiliar subject matter for lay readers by presenting origins.

An arrangement that suggested itself early on proved to have good logic: chronological, but skipping sideways, sometimes backward or forward, from facet to facet, stage to stage - national, metropolitan, state governmental, local - but always moving forward in time.

It proved impossible in the time available to write about each facet in each epoch broadly enough to do it justice, narrowly enough to keep the flow moving quickly, and still write the entire story of Oregon transportation planning to the present day. The result is a reasonably well-integrated history, but only up to the moment in 1974 when statewide planning goals, including Goal 12, the transportation goal, were adopted by the Oregon Legislature.

\section{FURTHER ACTIVITIES}

Extensive research and interviews were conducted dealing with events from 1974 to the present day. It is very much to be hoped that the rest of Oregon's transportation planning history, especially surrounding development of the Transportation Planning Rule and its adoption in 1991, will be written in due course. 


\section{INTRODUCTION}

On September 12, 2009, a new flock of Portlanders received an invitation to leave their cars at home. With the opening of the Green Line, TriMet, the regional transit agency, expanded its MAX light rail system to 53 miles of track serving five termini. For residents of growing neighborhoods in Oregon City, Canby, Happy Valley, Sandy and Damascus, suddenly NOT driving but commuting downtown by transit, became - maybe - a realistic option.

What goes into individuals' transportation choices? Some things are usually within their control: where they live, what they value, how they budget time. Most people are optimizers. Does it save money and time to take light rail? Or will running the lunchtime errands become too inconvenient without a car.

Some people will respond to pleasures of the new line. They will like watching the world go by, or riding with neighbors - maybe grinning from the oddity of a brand-new way of moving about. Some will be persuaded by a news story, a colleague's entreaty, or an office memo that it is up to them to do their share to reduce congestion, save oil, and slow greenhouse gas emissions.

Other things are less within people's control. The carless will feel relieved by the reduction of their enforced commute from 60 minutes by bus to half of that by rail.

One thing that most will not think to question is: who made this system? We certainly didn't. Cars and roads, driveways and freeways, trucks and trains - they just are. The same goes for the arrangement of places traveled from and to - home and shopping, school and work. We don't control the physical system that exists; we live with it. It mostly works.

However, anyone noticing the number and tone of local transportation and land use news stories will suspect that the system evolved through clamor and debate. This is true in most places; it may be especially true in Portland and it is plenty true throughout Oregon. Over the years, people have challenged most aspects of Portland's transportation system, and they continue to do so. Their style has spread to many places around the state. Often, citizens have shown that they do have some control, or at least influence.

Rarer are those who question the worth of automobiles. Not only do we live with cars, we really are stuck with them. They work, but they dominate. A strong car-despising subculture has existed in the U.S. at least since the early 1960s, and has its adherents in Oregon. Still, nobody believes automobiles can or will be done away with soon. Portland is renowned for transit and cycling, but most of its citizens drive. Suburbs are served well enough by bus, but are laid out for driving. Smaller cities work to maintain transit systems, mostly for the elderly and poor, but there and in small towns and rural areas, cars are simply what there is. 
There are many who consider car-hating false. "I wish we didn’t have to vilify automobiles, relative to transit," said Craig Greenleaf, who has worked as both a land use and transportation planner. "Road improvements are necessary to facilitate transit."

There are those who consider it pointless. Political scientist James Dunn argues for an "autoplus" world, "taming the excesses of automobile-based transport" but preserving personal mobility - which, in any case, will "never be given up once it is achieved."2

And admittedly, vehicle miles traveled (VMT) are few, by comparison, outside of cities. However, developing transportation options in places away from Portland would be of relatively small consequence for fuel conservation and greenhouse gas reduction were it not for the ways that cars enable distance, promote spread-out development, and shape commercial geography, vividly so in growing or booming towns such as Bend.

Much if not most of the state's transportation planning consists of planning for automobile use as well as freight transport by road, rail, water and air; long-distance passenger transport by rail and air; and systems, interconnections, and land use decisions that bring all of these together. In truth, more than one Oregon transportation professional who started out as a smart-growth crusader ended up dedicated to the realities of planning for a functioning "multimodal" system.

Even so, "multimodal" is often used as code for "fewer cars" and since the early "70s, an anticar, "multimodal" drumbeat in Oregon has kept the conversation bent toward practicable options and change in individual travel behavior, with notable successes. The VMT-reduction edge to both transportation and land use planning in Oregon has been given a huge boost by the specter of climate change.

With its statewide land use program, urban growth boundaries, Transportation Planning Rule (TPR), active (often activist) citizenry, progressive-dominated government, and, in Portland, modern history of transit investment and self-consciously alternative urban self-concept, Oregon has gone further, for longer, and been more successful than most places in pushing back against automobiles' dominance of environment, lifestyle, and landscape.

Two moments in time brought particular change. In shifting away from freeway-building in the 1970s, Portland-area and state planners decided that transportation decisions and infrastructure need no longer dictate land use but could serve it. And with the 1991 TPR, Oregon became a pioneer in managing what has been called the transportation-land use connection. The rule's drafting was a collaboration between road planners weary of seeing projects defeated and landuse planners and activists wanting to reduce VMT. It recognized roads not as lines on a map but as lineal land uses having land-use impacts. It demanded local transportation system plans that addressed all modes, weighed multiple options, and coordinated with land use policies favoring compact urban form. It also ensured that planned land uses would not overwhelm road capacity, to the delight of engineers. In all of these regards, it has not worked perfectly but it has worked.

${ }^{1}$ Craig Greenleaf, interview with author, August 2009

${ }^{2}$ James A. Dunn, Jr., Driving Forces, 1998, p. 169 
Whether in collaboration or acting independently, Oregon's idealists, activists, futurists and contrarians hold considerable power. Their first coalescence in the 1970s was thanks to an import, the anti-freeway movement. Their rapid evolution into a litigating anti-sprawl force, led by the watchdog group 1000 Friends of Oregon, became an export when "1000 Friends" groups sprang up in other states. PSU professors Sy Adler and Martha Bianco observe that Friends, as the dominant contrarians, function as a third agent within a "corporatist" arrangement, that is to say, mirroring unions in that they keep both government and the private sector on their toes"

But Friends and their allies are also dreamers. As with the TPR, a recurring dynamic in modern Oregon transportation (and land use) planning is between those who deal in what is, and those who deal in what could or ought to be. The two sides meet in practically every transportation planning debate - usually around the merits of more or fewer roads and highways, more or less land and distance dedicated to settlement.

These two sides met in the two biggest land-use-and-transportation debates in Oregon history the killing of the Mt. Hood Freeway and the defeat of the West Side Bypass, each of which directly brought about a new understanding of the relationship between land use and transportation - the land-use-first ethic and the state's "Goal 12" in the first instance, the TPR in the second. They meet again today in debate about proposed freeway bridge improvements between Portland and Vancouver, WA, called the Columbia River Crossing, possibly the granddaddy (grandson, actually) of all the state's transportation debates.

Throughout the history of Oregon transportation planning, Friends has played its part. So have other activists and organizations; planners and thinkers; politicians and civic leaders; lobbyists and business activists. With them, engineers, economists, wonks, transportation geeks, federal laws, national trends, and state and local cultures have played a role as well.

The story of Oregon's “multimodal” transportation planning must be written in such as way as to inform our commuter - the one tuning in to the transportation clamor - about the system he thinks just is, how it got there, and how and why he should appreciate its substance. As much as possible, the story, as it is begun here, relates complex subject matter to his life and times, delving into the big controversies that come from society's deep disagreement over conservation and development, aesthetics and wealth. It dips into older history, then moves more or less chronologically. In order to do justice to the various practitioners and players, it includes four stages of action: the national, the metropolitan, the state governmental and the local.

A full history to the present day would also attend to some of the less attended-to aspects of transportation planning, the ones that do not as often appear on newspapers' front pages. These include freight planning and its relationship to the business and corporate communities; the specialized work of modelers, system-design technologists, economists, and intelligenttransportation engineers; and the visions, dreams, schemes and projections of futurists, whose imaginings in bygone eras truly led to the very infrastructures we see today. Some current visions - from hydrogen highways to cycle-towns, bullet trains to electric-car cities, biofueled

\footnotetext{
${ }^{3}$ Martha Bianco and Sy Adler, “The Politics of Implementation,” PSU Center for Urban Studies, November 1998, p. 2
} 
states to right-priced thoroughfares - will become the daily environments of tomorrow, while other visions fade away.

In the full story of Oregon transportation planning to the present day, eight themes are prominent:

(1) The importance of money. It takes vast sums to build any large piece of infrastructure, and transportation infrastructures are as large and expensive as any. Meanwhile, even vaster sums are at stake in the connections, development opportunities and jobs that new (and lasting) transportation infrastructure represents; this influences every transportation planning decision.

(2) The creative tension between smart-growth planning advocates inside and outside of government and transportation professionals who are well-disposed toward smart growth but who have had their hard edges ground off by transportation realities.

(3) The cultural continuity among contrarian community activists, not only within but outside of 1000 Friends of Oregon, who with the Columbia River Crossing battle seek to extend this continuity.

(4) The large cultural and practical gulf, regarding transportation needs and perceptions, between the dominant Portland metro area and its satellite towns and every other part of the state.

(5) The equally vast - but also evolving - gulf between the Portland metro area and its Southwest Washington satellites, Vancouver and Clark County.

(6) The key, evolving problem of transportation planning for new and growing places such as Bend.

(7) The long-standing - and always evolving - creative tension between the two state agencies involved in transportation planning, the Department of Land Conservation and Development (DLCD) and the Oregon Department of Transportation (ODOT).

(8) And, finally, a lesson that is planners' daily bread but critical for thinking about 50 years' evolution: incrementalism. Something started now, whenever that now might be, creates increasing divergence over time from what would have been had the something not been started.

Dominated by the automobile we remain, even in Oregon. There are some who are perfectly content with that, and many more - the center, the majority - who simply play the reality game, dealing with what is. But in the modern history of Oregon transportation planning, there is a big place for what could or ought to be. 


\subsection{ANOTHER QUIET YEAR IN THE TRANSPORTATION NEWS}

As a point of departure, consider Oregon's current transportation issues and the ways they are discussed: probably not too differently from those in other places, but with plenty of environmentalist concern mixed in. This year, our imagined commuter, tuned in to the transportation debates, would have seen the Oregon Legislature pass House Bill 2001, raising $\$ 300$ million annually and funding billions in road and non-road transportation projects, as well as HB 2186, which adopts low-carbon fuel standards and mandates metro-area greenhouse gas emission planning.

A six-cent gas tax hike, the first since 1993, was approved as part of HB 2001 (and might go to voters if signatures are gathered), even while the state got national attention for experimenting with GPS-tracked mileage fees ${ }^{4}$ instead of gas taxes, which are generally considered out-of-date as a transportation funding mechanism. The state's Office of Innovative Partnerships is studying electric-car infrastructure, and Gov. Ted Kulongoski wants to attract electric-car manufacturers to the state. Tax breaks for hybrids are out, new ones for electric vehicles are in, and hydrogen cars are not yet fully discredited ${ }^{5}$.

Portland's regional government, Metro, unveiled its new Regional Transportation Plan identifying the Green Line's next sisters - light rail to Milwaukie, Lake Oswego, Sherwood, and Gresham via Powell Boulevard. (Richard Kidd, the mayor of overlooked Forest Grove, was not happy ${ }^{6}$.)

Oregonians were schooled in biofuel economics when two heavily state-subsidized corn-ethanol plants went bankrupt and a state ethanol fuel-percentage mandate was scaled back. However, new cellulosic ethanol technology may have found a viable feedstock and a new poster child in an enormous poplar plantation near Boardman ${ }^{7}$.

High-speed rail is coming! President Barack Obama wants it and Oregon wants to get in on it. Commuter rail from Beaverton to Wilsonville has begun, complete with a noise dust-up, and could be extended to Salem ${ }^{8}$; freight rail from Eugene to Coos Bay has gone missing ${ }^{9}$. Coos Bay wants a liquid natural gas port, but Astoria isn’t so sure.

\footnotetext{
${ }^{4}$ ODOT, “Oregon’s Mileage Fee Concept and Road User Fee Pilot Program,” 2007

${ }^{5}$ Roger Tattersall, "Devotee test-drives hydrogen fuel cars,” Portland Tribune 8/13/09, p. C7; Chris Paine et al, "Who Killed the Electric Car?” 2006

${ }^{6}$ Jim Redden, "Cities Fight to Avoid Being Left at Station,” The Portland Tribune, 8/20/09, p. 1

${ }^{7}$ Scott Learn, "Recession, new doubts take bloom off biofuels,” The Oregonian, 6/7/09, p. A1; Amy Hsuan, "Forest of Fuel,” The Oregonian, 9/6/09, p. D1; biofuel feedstock supplier is the Boardman plantation's third "career": it started as a paper pulp plantation

${ }^{8}$ Justin Carinci, “State studying WES possibilities,” Daily Journal of Commerce 7/7/09

${ }^{9}$ The Oregonian editorial board, "No way to run a railroad," 5/1/08
} 
Leaders in Coos Bay, distraught over geographic isolation, proposed for the nth time a completely new freeway, east-west across the south-central part of the state. They were supported by property-rights groups, but dismissed otherwise.

A Newberg-Dundee bypass, an expensive new rural highway planned in order to save two carclogged wine-country towns (clogged in part thanks to a casino), creeps toward realization and has held a spot in the top-ten transportation stories for a decade; \$192 million in state support created some of the loudest howls of the year, from bypass opponents.

Erstwhile boomtown Bend bought faulty city buses but still really wants to try transit ${ }^{10}$, even while local leaders are focused on roads, interchanges, parkways, highway access, tweaking Salem noses (in company with many others outside the Willamette Valley), and building a new neighborhood called Juniper Ridge, its single access located amid a swarm of big-box stores on a five-mile commercial strip.

Big nationwide transportation stories concerned automaker collapse, road stimulus funding and the dangers of driving while text messaging, which also was banned by Oregon along with nonhands-free cell-phone use. The national transportation bestseller was Tom Vanderbilt's Traffic: Why We Drive the Way We $\mathrm{Do}^{11}$.

In Portland, east-side streets will sport extensions of the Portland Streetcar. Ray LaHood, the national Secretary of Transportation, visited town for the launch of the first American-made (Oregon-made) streetcar in 56 years, declaring Portland the "livability capital of America."12

Nimby-ism raised its head, first in West Linn, with local residents opposed to an embankment futuristically covered with solar panels to power freeway lights, and then in Ardenwald, part of Milwaukie, where planned light rail tracks will pass too high in the air for nearby residents' comfort $^{13}$. But with completion of the Green Line and Metro’s new plan, light rail is riding high.

Cycling is, if anything, riding higher. Bend calls itself America's best mountain-biking town; Eugene is considered one of the nation's best bike towns, period; and the legend of Portland as cycle-town is growing to rival the city's light-rail fame. This year new bike lanes, bike routes, bike maps, and intersection "bike boxes" debuted. A hotly disputed freeway bike bridge almost became reality. Four bike-sharing organizations vied for a city-sanctioned franchise. Conflicts flared over bike fees, bike deaths, bike rights, and bike attitude. Portland boasted the nation's

${ }^{10}$ Dennis Luke, interview with the author, June 2009; Patrick Cliff, "Planning a route to regional transit," The Bend Bulletin, 8/10/09

${ }^{11}$ Tom Vanderbilt, Traffic: Why We Drive the Way We Do (and What It Says About Us), New York, Knopf, 2008

12 Ray LaHood, speech at Oregon-made streetcar launch, Portland, 6/29/09

${ }^{13}$ Matthew Graham, “Ardenwald neighborhood livid about light-rail bridge,” The Clackamas Review," 6/3/09 
second-highest bicycle commuting rate as well as a definitive bike-culture book, Pedaling Revolution, written by Oregonian reporter Jeff Mapes ${ }^{14}$.

Soaring above all other stories in media coverage - and rancorous dispute - was the latest tilt at solving a longstanding problem. The Columbia River Crossing, a bi-state fix for clogged commuter and freight traffic to and from Vancouver, emerged from a multiyear planning process as a physical-environment-bending, 12-lane bridge. The Crossing's emergence coincided with that of a new environmental issue: climate change. Bridge opponents reacted with horror to a project that seemed to fly in the face of the looming crisis, to say nothing of 35 years spent resisting big, automobile-oriented projects. Locals for and against the bridge got schooled in the nuts and bolts of tolling, congestion pricing, and induced demand.

And transportation talk continued its rise to the pinnacle of civic discourse through the work of devoted, transport-obsessed bloggers and activists at portlandtransport.com, pdxtransit.com, pdxtrains.blogspot.com, and rantingsofatrimetbusdriver.blogspot.com. Cyclists have their own champions and chatter at bikeportland.org and bta4bikes.org; anti-Columbia-River-Crossing activists host smarterbridge.blogspot.com and stopthecrc.wordpress.com; and even the anti-lightrail community is a presence, at saveportland.com.

14 Jeff Mapes, Pedaling Revolution, Corvallis: OSU Press, 2009 


\subsection{THE TOP OF THE FERRIS WHEEL}

In terms of what is happening in local transportation planning, policy and implementation, what shows up in the news represents the tip of an iceberg. The day before the Green Line's launch, Oregon Congressmen Earl Blumenauer and Peter DeFazio were at PSU for the Transportation Summit. This was a multifaceted conference for transportation professionals from city, county, state and federal departments; research institutions; academe; and private planning, engineering and innovation firms. The summit was hosted by the Oregon Transportation Research and Education Consortium (OTREC), a federal center established within Oregon's university system thanks to earmarked money from the 2005 federal transportation act called "SAFETEA-LU."

The "Safe, Accountable, Flexible, Efficient Transportation Equity Act: A Legacy for Users" had been the latest in an unbroken string of federal transportation acts dating back to the Federal Aid Road Act of $1916^{15}$. As with other big, issue-specific federal authorizations (such as farm bills), these packages of transportation policy, regulation, program-creation, and funding had evolved into a hexennial (sometimes quadrennial) Washington tradition.

The tradition of fancy naming began only with the very progressive, transit-oriented Intermodal Surface Transportation Efficiency Act of 1991, called "ISTEA" (before that, the Surface Transportation and Uniform Relocation Assistance Act of 1987 did not rate an acronym).

"I guess I am the last man standing from the 1973 Oregon legislature, where we authorized a multimodal statewide transportation plan - nearly 20 years before ISTEA!” Congressman Blumenauer told gathered OTREC grantees in his enthusiastic, animated way.

In one breath, the Congressman named the two modern heydays of transportation planning - the early '70s and the early '90s - and the holy grail of both: multimodality. It was clear that most attending the Transportation Summit believed a new heyday was at hand, that their car on the national transportation ferris wheel was once again nearing the high point, up in the bright sun of reason, making it just about a 20 -year round trip.

“I hope we will reset the nation's transportation policy,” DeFazio told summit attendees, referring to SAFETEA-LU's imminent expiration and Congress's hearty rejection of President Obama's wish to delay the next acronym for 18 months. "We have been limping along on the vision of Dwight David Eisenhower,” DeFazio suggested.

In that breath, DeFazio took the transportation timeline back yet another 20-year cycle, to the early '50s - also a heyday, but in the mythology of multimodal transportation planning a sorrier one, when the vast interstate highway system was created, its final authorization coming with the 1956 Federal Aid Highway Act.

${ }^{15}$ For thorough compendium, cf. http://en.wikipedia.org/wiki/Federal-Aid_Highway_Act 
From his place of honor on the all-star summit keynote roster featuring PSU President Wim Wiewel, Portland Mayor Sam Adams, and retired TriMet guru Dick Feeney, DeFazio promised Oregon would be a laboratory for new transportation policy. He described four hoped-for tenets of the coming reauthorization: reduction of carbon emissions, accountability for dollars spent, “least-cost” engineering, and integrated land-use and transportation planning.

The fourth tenet rang loud bells for most in the room. Following Oregon's passage in 1973 of SB 100, which created statewide land use planning, an exuberant parsing began of just what land use planning meant. From the beginning it was accepted that transportation planning was a key to land use planning, and the 14 broad planning goals adopted in 1974 included Goal 12 Transportation.

Goal 12 began as two goals, one for urban mass transit and another for freeways and major highways. As it happened, the swirling, early-70s land use dialogue based in Salem tapped into an even louder one occurring in Portland, also channeling the environmental, activist, and oilshortage sensibilities of the time. That dialogue would lead to the scuttling of two planned freeways, the birth of Portland-area light rail transit, and formulation of the grail of multimodality.

“The Board believes,” said a document adopted in March 1974 by the Columbia Region Association of Governments (CRAG), the precursor to today's Metro, "that our goal should be to develop an integrated multi-modal transportation system. ... The consultant to the Governor's Task Force on Transportation has recommended a transportation and comprehensive planning program that should be endorsed and implemented."16

The governor was Tom McCall, a former KGW-TV newscaster and Secretary of State who served as governor from 1966 to 1974 . The consultants were called System Design Concepts ${ }^{17}$. And the task force was the brainchild of Neil Goldschmidt, the future governor who was then Portland's mayor and a principal architect of the dawning new era in Portland-area transportation.

CRAG's goal was a waypoint and the harbinger of a new ethic in transportation and land use planning. At the state level, as they did with the 13 other goals, the SB 100-created Land Conservation and Development Commission (LCDC) thought promptly and with some depth about land use implications.

“A transportation plan,” their Goal 12, adopted in December 1974, finally declared, "shall consider all modes of transportation including mass transit, air, water, pipeline, rail, highway, bicycle and pedestrian ..., [shall] consider the differences in social consequences that would result from utilizing differing combinations of transportation modes ... [and shall] avoid principal reliance upon any one mode of transportation ....”

\footnotetext{
16 “CRAG Transportation Goal adopted March 15, 1974,” Oregon State Archives, LCDC records, 7/19/74

${ }^{17}$ System Design Concepts, “The Cooperative Transportation Planning Process in the Portland Metropolitan Area,” January 1975
} 
"Plans for new or for the improvement of major transportation facilities," the Goal continued, "should identify the positive and negative impacts on: (1) local land use patterns, (2) environmental quality, (3) energy use and resources, (4) existing transportation systems and (5) fiscal resources ...”

It was a solid effort. Over the next 12 years, transportation planning became part of every city's and county's comprehensive land use plan.

Ultimately, however, the state would need something more specific than policies and appropriate language written into local plans. It would need firmer direction for jurisdictions seeking either to site land uses that would require or impact transportation facilities, or to site transportation facilities that would create new access and thus impact travel times, land values, and development potential. This was the most significant transportation-land-use connection to be dealt with, one among many.

In the early '90s, cultural and political riptides pulled the nation and local communities in contradictory directions. The final lap for 12 years of a conservative federal administration, high times for the anti-environmental Wise Use movement, and the start of a mid-East war coincided with important national environmental legislation, including 1990 Clean Air Act amendments, 1991's ISTEA and, in 1992, the developed world's first ratification of a climate-change treaty ${ }^{18}$. Locally, tax-limiting Measure 5 arrived along with completion of Metro's visionary 2040 Plan, a green light for west-side light rail, successful resistance against a controversial west-side freeway bypass, and the state's 1991 Transportation Planning Rule (TPR), at last implementing Goal 12 in tangible ways.

The land use debate, begun in earnest with SB100, was about trying to arrange human settlement in efficient, utilitarian, compact, and aesthetically tolerable ways. In this it always bucked certain human behaviors usually exhibited within a system of free markets, status and choice: living in low-density suburbs, exurbs, the rural-urban fringe and truly rural areas was a post-war and to some extent a pre-war promise on which dreams (and fortunes) were built.

The transportation debate, begun with the “withdrawal” of Portland's Mt. Hood Freeway in 1974 although not truly extended statewide until the TPR, was also about efficiency, support for land use goals, and even aesthetic tolerability. It also bucked human behavior, but in that regard it had an even harder row to hoe since the behavior it bucked was driving cars.

\footnotetext{
18 The U.N. Framework Convention on Climate Change (UNFCCC), U.S. ratification signed by
} President George H.W. Bush on October 13, 1992 


\subsection{AUTOMOBILE NIGHTMARES}

The conundrum of personal (non-freight) transportation is that human beings are large-ish, brainy yet physically soft and slow creatures who are activity-oriented, movement-oriented, distance-fascinated, play-seeking, competitive and maximizing, independent and territorial, yet who have always survived by increasing their numbers and living in groups.

The work of getting humans where they wanted or needed to go, as quickly and comfortably as possible, with minimum effort and, as time went on, with maximum self-containment, was a sort of central project of civilization warranting every possible investment of brain, technology, and resource. In times of war - pretty much throughout human history - having the best transportation was a key to victory, and losing was not pleasant.

The current state of development of the ideal - at least the most in-demand - form of human transportation is, and has been for just over 100 years, the automobile. This is true in U.S. cities as well as those in Europe, Asia, and the developing world. It is true in rural areas to the extent that roads exist to support transport.

Investment in roads, of course, stemmed in large part from getting goods to market and back home again (and delivering mail!), but once roads existed, owning a personal vehicle usually became the norm and the aspiration. For anyone with adequate resources, owning an automobile meant independent mobility and economic advantage. Republican President Ronald Reagan, in the pre-ISTEA era, echoing the car-love his generation grew up with, called automobiles "the ultimate freedom.” They are considered desirable pretty much everywhere on the planet: Chinese cities once bedecked with bicycles now sport vehicular traffic jams, and even Europe's best transit cities are still full of motor vehicles (carless Venice being about the only exception).

With all of that, the automobile has big and obvious problems, and these are perceived by most people in most places. It runs on liquid fuels that have been in abundance but now become harder to come by, creating huge economic and political stresses. These fuels' exhaust pollutes the air in and around human centers of activity. The automobile is fascinatingly enormous and inefficient, using many hundreds or thousands of pounds of metal machinery to move 150-pound humans around individually or in groups. It is ultimately hedonistic, making it all but effortless to get from home to work to places of recreation and commerce.

Probably more than anything, the automobile - due to our size, its size, the speed demands of our lifestyles and the safety demands of our vulnerable bodies - dominates our environment. It does so in at least four ways: by the physical reality of the extensive pavement on which it runs; by its own very presence and numbers; by its impact on the nature and arrangement of places; and by its dependence-creating facilitation of distance.

It is difficult to get a handle on, or find meaningful expression for, the degree of this dominance. People are everywhere; their activities are the very stuff of civilization and society; and everywhere people are, cars are. Yes, it is human movement that makes inhabited places vibrant 
and creates commerce, but when practically every human movement occurs encased in a six-byfifteen-foot machine, the reality has grown physically out of proportion.

For most of the post-car-love era, this dominance of the human environment has topped the list of grievances causing individual actors to tip over into open rebellion against the automobile. Two relatively recent books reflected and influenced debate: The Geography of Nowhere, from 1994, by James Howard Kunstler ${ }^{19}$, and Asphalt Nation, written by Jane Holtz Kay in $1997^{20}$.

But a generation before them, in 1972, Ron Buel, a member of Goldschmidt's staff in Portland, wrote a similar book entitled Dead End: The Automobile in Mass Transportation - How We Got Where We Are, How We Can Turn Around ${ }^{21}$. In Oregon's case, it was elements of physical domination - freeways that would tear up neighborhoods, seas of downtown parking - that would be the poster children for revolution.

Once automobiles became suspect, other grievances such as waste and pollution were not insignificant. Today, the matter of climate change, exhibited in Oregon conversations at the level of news, advocacy, policy, casual conversation and dispute, has topped the grievance of physical domination. At issue is the extent to which all human uses of carbon-based fuels produce carbon dioxide emissions (now usually called pollution), which, along with other compounds in smaller amounts, act as solar-energy-trapping greenhouse gas exacerbating gradual climate warming. At particular issue is personal automobiles' share of $\mathrm{CO}_{2}$ emissions - about $15 \%$ in the U.S. (22\% for all road transportation in the U.S., $10 \%$ worldwide) ${ }^{22}$. The climate-change problem is considered so threatening that it has brought action at state, federal, and international levels.

From physical and technological perspectives, although not necessarily political ones, the personal transportation contribution to greenhouse gas ought to be solvable without too much difficulty. Government and private-sector innovators tackle it from three directions: reduction in vehicle use (or vehicle miles traveled, VMT, as through compact development, mass transit, bicycle use, pricing, and, ultimately, culture change); reduction in greenhouse gas emissions through changes in the type of vehicle power plant used (electric, hydrogen, potentially certain biofuels); and changes in vehicle size and efficiency, per unit of energy used (higher miles per gallon of petroleum or biofuel, or miles per unit of electric charge).

Not that it will be easy, but it should be doable. In matters of efficiency and power plant, the causal agents - automobiles - are easily traded out; they age quickly and can be replaced in short order, if the will is there, by newer and different ones (cash for clunkers!). This is so although the automotive industry's infrastructure and economics have proven stubbornly intractable.

\footnotetext{
19 James Howard Kunstler, The Geography of Nowhere, New York: Touchstone, 1994

${ }^{20}$ Jane Holtz Kay, Asphalt Nation, Berkeley: UC Press, 1997

${ }^{21}$ Ron Buel, Dead End: The Automobile in Mass Transportation - How We Got Where We Are, How We Can Turn Around, Englewood Cliffs, NJ: Prentice Hall, 1972

${ }^{22}$ John Conti, “U.S. Greenhouse Gas Emissions in the Transportation Sector,” Energy Information Administration, U.S. Department of Energy, July 2009
} 
The problem of vehicle miles traveled is harder. New transit does get built, as Portland's MAX demonstrates, and high fuel prices in 2007 did prove effective in causing changes in travel behavior, reducing VMT nationwide by about 11 billion miles (a 4.3\% decline from March 2007 to March 2008) ${ }^{23}$. But behavioral changes are limited when home and daily destinations are arranged in such a way that alternatives to individual motor transportation are barely practical. We have made our needs from our environment be all about distance; we are movementdependent, machine-transport dependent, and for now, automobile-dependent. American cities are the epicenter of this problem, but much of the developed and developing world, when built out, is built out following the dictates of automobile transport.

So, economically practicable new fuels can be and already are being developed to replace petroleum. First-generation liquid substitute fuels already create fewer sulfur and nitrogen oxides and carbon particulates. Second-generation, non-liquid fuels, particularly electricity (especially if generated renewably), are in line to start lessening greenhouse gas emissions. Automobile size and weight are gradually shrinking. With these changes and with the increasing cost of driving, which will result in part from overdue attention to "right-pricing" the private use of public domain, particularly in cities, the universal and unreflective advantage taken of automobiles' hedonistic comforts is due to lessen.

However, after all of this, still the automobile's dominance of our environment will be the symptom least easy to correct. We still live in a built world - likely to be as durable and enduring as all the centuries' worth of built worlds that we still maintain - defined by pavement, parked and moving cars, car-shaped and car-arranged amenities, and everyday distance. The way that Oregon got here is the way that every other state got here.

${ }^{23}$ Lena H. Sun, “Travelers Turn to Public Transit,” The Washington Post,” 6/3/08 


\subsection{EARLY OREGON ROADS}

In $19^{\text {th }}$ century Oregon, before automobiles, there were wagon roads or riverboats, barges or railroads linking most of the same towns that exist today, small agricultural settlements that they then were. The Barlow Road, a private toll road around the south side of Mt. Hood, was Oregon's first road in 1843. By 1851, a 10-mile Tualatin Valley plank road had been laid to bring wheat to Portland's waterfront. Road quality was atrocious; in 1866, seven years after statehood, all men aged 21-50 were required to work two days per year building and maintaining county roads ${ }^{24}$.

The national "Good Roads" movement was actually started by bicyclists, the League of American Wheelmen, around 1880. With the invention and spread of the automobile not long after, Good Roads became co-opted as a cause that would gradually compel huge governmental transport investment. New Jersey passed the first "state-aid road act" in 1892; the U.S. Department of Agriculture created the Office of Road Inquiry the following year. Lobbying for federal road funding was in full swing by the turn of the century, but did not bear fruit until $1916^{25}$.

Oregon's first automobile was purchased by E.H. Wemme in 1899. Washington businessman and booster Sam Hill and Governor Oswald West guided the Good Roads movement locally, working for development of quality long-distance roads in Oregon, a bit behind neighboring states. "Good roads are more than my hobby; they are my religion," Hill once said ${ }^{26}$. He built the region’s first paved roads on his own land in Maryhill, WA, at his own expense, in 1911.

Hill and West zeroed in on the 1913 legislative session to jumpstart state road planning and funding. Hill lectured throughout the state to generate awareness of roads' benefits, and he invited West and the entire 88-member Legislature to Maryhill for a confab. Next, the pair charmed Portland's business elite into supporting and funding the political campaign, having also inspired key members to fund the Columbia River Highway, planned starting in 1909.

It all worked, with the Columbia River Highway's intensely aesthetic design used effectively to tap into the public's new auto-inspired touring fantasies ${ }^{27}$. The 1913 Legislature created the state Highway Department and its slogan, “Get Oregon Out of the mud,” along with an executive Highway Commission headed by West. It also appropriated \$250,000 a year for road development, funded through property taxes ${ }^{28}$.

\footnotetext{
${ }^{24}$ ODOT, “Oregon on the Move, a history of Oregon’s transportation systems,” n.d.

25 John E. Tuhy, Sam Hill, The Prince of Castle Nowhere, Portland, Timber Press, 1983, pp. 129156

26 Ibid.

${ }^{27}$ Ibid.

${ }^{28}$ ODOT, “Oregon on the Move,” p. 12; Tuhy, Sam Hill
} 
(West persuaded legislators to make the entire beach Oregon's first "highway," to reclaim it from those who would own it and to exercise the new department's wings. According to former Metro head Mike Burton, West did this by calling the anti-beach-highway Senate President to his office, locking him in, then going downstairs for the successful floor vote ${ }^{29}$.)

April 22, 1914, was proclaimed Oregon Good Roads Day, and that year the new commission approved the state's first Highway Plan. This included nine key routes, foremost among them Oregon's Portland-to-Ashland-to-California leg of the then-named Pacific Highway, the key inland route from Canada to Mexico. The other routes were from Seaside to Pendleton along the Columbia River; Pendleton to Ontario; Seaside to California along the coast; Portland to Albany, parallel to the Pacific Highway; The Dalles to Klamath Falls; Wasco to Lakeview; Eugene to Prineville; and Bend to Ontario ${ }^{30}$.

Within a decade, all nine routes and several others were largely complete. In 1924, the state highway system consisted of 4,464 miles of roads, 720 miles of them paved and another 1,861 miles surfaced with crushed rock. This was thanks to the 1917 authorization of \$38 million in bonds plus $\$ 6$ million more for truck roads, dedication of vehicle license fees to the Highway Fund, and passage in 1919 of the nation's first gas tax, a penny a gallon. In 1924, there were over 200,000 automobiles in the now-connected state ${ }^{31}$.

County roads, the unheralded sisters of state highways, always far exceeded them in total road miles - although in the modern era these roads have been the subject of relatively few transportation planning disputes, due in part to Oregon's restrictive rural zoning laws. Deschutes County's road development history tells a typical tale: 143 miles of county roads created before the first year reported, 1879; 34 more miles by the turn of the last century; 52 more before 1910; 223 more by 1920; and another 148 in the ' $20 \mathrm{~s}^{32}$. Throughout the state, county resources were devoted to gradual and continuous opening of farm and market roads.

${ }^{29}$ Mike Burton, interview with the author, May 2008

${ }^{30}$ ODOT, “Oregon on the Move,” p. 13; Tuhy, Sam Hill

${ }^{31}$ ODOT, “Oregon on the Move,” cf. p. 25

${ }^{32}$ Deschutes County, www.co.deschutes.or.us, Road Reports, “County Road Establishments by Year” 


\subsection{PETROLEUM, THE VHS OF AUTO FUELS}

Early in the 2006 documentary Who Killed the Electric Car, it is noted with chagrin that "one hundred years ago, there were more electrics than gas-powered automobiles. By 1920, the internal combustion engine had won.”

Ethanol activist David Blume, in his 2007 book Alcohol Can Be a Gas, notes with equal chagrin that an "enterprising automaker of the [early 1900s] era preferred alcohol as a fuel. In fact, until 1931, Henry Ford's automobiles, including the Model T and later the Model A, were designed to run on either alcohol or gasoline .... Ford envisioned a day when the Industrial Revolution would benefit the rural landowner ....”33

Today, both electricity and alcohol as fuel systems for powering cars are making a comeback; back then, both were outcompeted by the upstart, gasoline. Blume asserts that John D.

Rockefeller's principal product at Standard Oil was kerosene, distilled from petroleum and used for boilers and lighting. The volatile by-products were toxic waste, but eventually Rockefeller found a way to refine them into gasoline to run internal combustion engines.

Blume, who believes in cooperative rural ethanol production, sketches out a conspiracy whereby the petroleum industry, which hated alcohol as a competing fuel, ruined a cooperative rural alcohol-production movement that started in Germany and was thriving in the rural U.S. The industry first slammed the movement at the outbreak of World War I as a dangerous foreign idea, then supported Prohibition, which killed it - at least long enough for gasoline filling stations to sprout everywhere.

Canadian Darryl McMahon, who tracks electric vehicle technology at his website, econogics.com, believes that in fact, electrics were always far outsold by liquid-fuel vehicles, but still were holding their own into the nineteen-teens in terms of range, speed, and popular acceptance. Then in 1913, Chevron built the first gasoline station, "which started a boom in the building of these facilities until they were ubiquitous ... by 1920. In 1916 alone, over 200 petroleum companies were established in the U.S., which coincides neatly with the decline of the electric car. Electrical recharging facilities were not nearly as common. Many 'service stations' would not have had access to an electrical grid at the turn of the century.”

${ }^{33}$ David Blume, Alcohol Can Be A Gas!, Soquel, CA: The International Institute for Ecological Agriculture, 2007, pp. 9-16 


\subsection{EARLY METRO-AREA MASS TRANSIT}

The rise and fall of early- $20^{\text {th }}$-century streetcars and interurban railways is a tale more often told than that of early electrics and alcohol vehicles. Considering modern efforts to rebuild urban rail transit capacity, the fact of these lines' past existence and the extent of their former influence and physical reality sits like a huge and weeping child in the middle of the transportation planning story.

The map from one of Dick Pintarich's chapters in the book he also edited, Great and Minor Moments in Oregon History, is gasp-inducing. Interurbans run by five private companies once laced greater Portland and the Willamette Valley, with three lines out across Washington County; three more into Clackamas County with termini at Bull Run, Cazadero (past Estacada), and Mount Angel in Marion County; lines from Portland to Vancouver, McMinnville, and Eugene; and a west-side line from Forest Grove to Corvallis via Carlton, Amity, and Independence, which must have been sublime. The line to Oregon City ran every half hour past Oaks Park, which had been built by the transit company to attract ridership ${ }^{34}$.

Inner Portland's streetcar system was not much less impressive, with west-side lines to Multnomah, Hillsdale, Council Crest, Washington Park, Pittock Mansion, and Willamette Heights ${ }^{35}$. Like Oaks Park, the Vaughn Street baseball park, home to the Portland Beavers, was built by transit developers in order to attract riders ${ }^{36}$. East-side lines ran out along all of the same streets which (no coincidence) in the last 15 years have anchored Portland's east-side neighborhood renaissance: Woodstock, Clinton, Division, Hawthorne, Belmont, Glisan, Sandy, Broadway, Alberta and Killingsworth.

The first electric streetcars opened in 1889 (after 17 years of horsedrawn operation), and the first Portland-to-Oregon-City interurban (actually one of the first in the U.S. and the first to use longdistance electric transmission) opened in $1893^{37}$. Both systems had their heyday in the years just before World War I; the last streetcar ceased operation in 1950, and the last interurban in 1958.

Electric rail mass transit and the automobile began together, at the same moment in time. One peaked as the other surged, one died as the other peaked, and one was reborn as the other lost its luster. Automobiles and mass transit always had an inverse relationship.

This is not to say that automobiles' success at mass transit's expense was due to a simple struggle between proponents. Nor was it simply due to collusion and corporate greed on the part

\footnotetext{
${ }^{34}$ Dick Pintarich, "The Rise and Fall of Oregon's Electrics," in Pintarich, Great and Minor Moments in Oregon History, New Oregon Publishers, 2003, pp. 190-202

${ }^{35} \mathrm{Cf}$. www.vintagetrolleys.com

${ }^{36}$ Cf. William Cornett, "Vaughn Street Park and the Great Baseball War of 1903,” Northwest Examiner, October 2009, pp. 22-3

${ }^{37}$ Tri-Met, "A history of public transit in Portland," http://trimet.org/about/history/transitinportland.htm
} 
of General Motors, Standard Oil, and Firestone Tires, a common and powerful myth. PSU's Adler makes these points in the case of Los Angeles in an award-winning 1991 article, "The Transformation of the Pacific Electric Railway,” and elsewhere for other U.S. cities ${ }^{38}$.

Big problems for first-generation rail mass transit were changing urban form and a worn-out private-business model. The case of L.A., which had the West's most vaunted system and its biggest transit collapse, is instructive. There, multiple new "downtowns" wanted economic autonomy and their leaders competed for business. Most thought transit favored central L.A. and preferred a more networked system (i.e., buses and, eventually, freeways). Even earlier, though, streetcars were already yielding to cheaper buses, while some passenger transit owners wanted to get into the more profitable freight business. Everybody loved freeways, even downtown businessmen; they just wanted them radial rather than networked.

Potent transit advocates fought into the '50s to revivify L.A. streetcar and interurban lines, then still in private hands and struggling. However, suburban pressure caused their best plans to be co-opted. First rail transit was to be included within rights of way for that newfangled thing, the freeway. Then those plans were jelling too slowly, so rail was relegated to subways, someday nearly 40 years later, as it turned out.

In L.A., dissent also blocked municipal acquisition of the failing private system until it was far too late. "It is regrettable," wrote Stanford economist John Due in 1960, "that government units did not take over the [L.A. rail transit] system in the mid-thirties, when it was still intact ... and recognize the importance of continued use of the rail facilities in the over-all solution to the transportation problems in the area."39 The issue would play out over 20 years in local and federal politics.

Meanwhile, according to Bianco, in L.A. and in every other city, private transit companies became increasingly invested in buses, the only way to meet government's requirement that they serve increasingly spread-out, unprofitable routes ${ }^{40}$. GM's hidden subsidiaries did buy up and dismantle plenty of rail transit systems, substituting their own diesel buses - but the systems were already dying or dead from suburbanization and lack of civic intervention.

Automobiles, and users' love of the lifestyle they afforded (realtors loved it, too), facilitated suburbanization in the first place, even though "streetcar suburbs" had preceded them. As Bianco put it, "What if we have met the enemy, and the enemy is us?" 41 Not GM, that is - drivers.

${ }^{38}$ Sy Adler, "The Transformation of the Pacific Electric Railway: Bradford Snell, Roger Rabbit, and the Politics of Transportation in Los Angeles," Urban Affairs Quarterly 27-1, Se 1991, pp. 51-86; Cf. Sy Adler, “The Evolution of Federal Transit Policy,” in Martin A. and Martin V. Melosi, Urban Public Policy, Penn State, 1993, pp. 69-99

39 Adler, “The Transformation of the Pacific Electric Railway,” p. 59

${ }^{40}$ Martha Bianco, "Kennedy, 60 Minutes, and Roger Rabbit: Understanding Conspiracy Theory Explanations of the Decline of Urban Mass Transit,” PSU Center for Urban Studies, Discussion Paper 98-11, November 1998

${ }^{41}$ Ibid. 
In Portland and environs, electric rail started fading early, almost as soon as it got off the ground. In Bianco's systematic assessment in her 1994 dissertation, by 1915 the electric lines were already in financial trouble due to service demands from city and state regulators, fare demands from riders, wage demands from employees, and competitive demands from other transit companies that had caused too-rapid expansion ${ }^{42}$ (to all those lovely termini). Later, as in L.A., car-love, suburbanization, place-based competition, freeway development and lack of government intervention would hasten the electrics' end.

Two other nationally occurring phenomena also were prominent in Portland transit's troubles as early as the '20s. Traffic jams arose as the growing number of automobiles hampered on-street rail carriages entering the city center, and off-peak fares declined as automobiles became the leisure-mode of choice, with transit used mostly for commuting.

The bottom line, for Bianco, was that Oregon's early electric-rail industry "was a victim of the irreconcilable conflict between its profit motive and the service duty mandated by its franchises and expected by its constituencies."${ }^{, 43}$

${ }^{42}$ Martha Bianco, "Private Profit Versus Public Service: Competing Demands in Urban Transportation History and Policy, Portland, Oregon, 1872-1970,” PhD dissertation, Portland State University, 1994, pp. 53-55, 251-261

${ }^{43}$ Bianco, “Private Profit Versus Public Service,” p. 55 


\subsection{THE INTERSTATES}

The Good Roads movement made long-distance automobile travel practical; the Interstate and Defense Highways program was its apotheosis. Modeled on the autobahnen started by Adolf Hitler in 1935, the U.S. interstate system was conceived by Thomas H. MacDonald, chief of the federal Bureau of Public Roads, and his top aide, Herbert S. Fairbank ${ }^{44}$. The two men shepherded their dream through 20 years of fits and starts to full funding in 1956.

Federal highway money first began to flow after World War I when farmers wanting farm-tomarket roads and Rural Free Delivery joined the Good Roads movement. Advocacy from the American Automobile Association (AAA) and the American Association of State Highway Officials (AASHO) led to the Federal Aid Highway Act of 1916 authorizing \$25 million for improvement of "rural post roads."

Said Warren Harding, on his way to a 1920 presidential landslide, “... one of the greatest economic problems, if not the greatest problem of modern civilization, is distribution. There can be no doubt of the position of the good roads movement in the solution of the problem."45 Federal aid grew.

Franklin Roosevelt, unfortunately perhaps, knew that putting people back to work meant building roads. MacDonald's plans were set in motion at the height of the Depression; federal gas taxation began in 1932 and the 1934 authorization bill told states to use $1.5 \%$ of their federal highway money for a comprehensive national survey of road conditions, use, and financing. The 1938 report based on the survey's findings, called Toll Roads and Free Roads, featured a "Master Plan for Free Highway Development" describing a toll-free network of express highways, grade-separated and with limited access, which would evolve into the interstate system. Based on the survey - and in consultation with the Department of War - MacDonald and Fairbank proposed the system's initial 26,700 miles.

The interstate system consisted of two distinct components: the "interregional" highways upgrading rural roads to link cities across hundreds of straight miles, and the urban highways intended to relieve the greatest problem identified in state surveys, namely urban congestion. Increasingly, busy intercity trucking routes entered cities along old highways that had become streets. These were hard to widen and had become a congested mess. The 1938 prescription was for completely separate, limited-access expressways that drilled into, under or over cities, forming elevated or sunken rings around downtowns and bigger rings serving suburbs.

\footnotetext{
${ }^{44}$ Richard F. Weingroff, “Designating the Urban Interstates,” US Department of Transportation, FHWA: http://www.fhwa.dot.gov/infrastructure/fairbank.cfm

${ }^{45}$ Richard F. Weingroff, "Clearly Vicious as a Matter of Policy: The Fight Against Federal Aid” Part One, "Unease in the Golden Age,” US Department of Transportation, FHWA: http://www.fhwa.dot.gov/infrastructure/hwyhist04a.cfm
} 
On the other hand, one publication (just hearsay, as it was not located by the time this was written) is said to have argued that only with gas-tax revenue from urban freeways could the interstates have been built at all ${ }^{46}$.

As much as congestion, the program aimed at the famous ill called "urban blight.” Downtowns, the report said, were "cramped, crowded, and depreciated"; beyond them lay the "slum area where living conditions are poor. Around the slums is an even larger area of residential property in various stages of depreciation. This is the widely discussed 'blighted area.' Without the application of effective rehabilitation measures, it will become part of the city's slums.”

Ironically, the report accurately blamed the automobile for urban flight and for suburbs extending "far out beyond the city limits ... merging almost imperceptibly into the farm lands." It made urban expressways the very centerpiece of a revitalizing new planning regime, which would have to "provide the greater space now needed for the unfettered circulation of traffic, and ... permit a reintegration of facilities for the various forms of transportation - railway terminals, docks, airports and the highway approaches to each - more consistent with their modern relationships." ${ }^{47}$ It recommended haste in buying rights of way - while land values in "blighted areas” were still low!

But action had to wait for two foreign wars, election of a new and highway-obsessed soldierpresident, and many battles among states, regions, and urban and rural constituents for their fair share of federal money and attention. As in L.A., freeways were widely seen as a hot ticket. The mid-war 1944 Federal-Aid Highway Act freed \$500 million precious dollars for planning; the postwar boom galvanized attention toward cities and jobs. After the Korean War, constituents were still arguing; a 1955 authorization bill failed. Finally, urban legislators got a glimpse of the goods they'd be getting, courtesy of a publication called the Yellow Book (later discarded). This swung enough votes to pass the 1956 Federal-Aid Highway Act, spending \$32.9 billion for 90\% of the cost of 41,000 miles of freeway, coast to coast, into and around every major city.

Very much to their credit, MacDonald and Fairbank (both of whom retired before final passage) always believed that correcting urban ills (albeit through freeways) would involve coordination with city and perhaps new regional planning authorities. To their discredit, they scoffed at city planners' growing concern that urban freeways would hasten suburbanization. In any case, no mandate for coordination was included in the final act, nor any incorporation of transit.

According to Richard Weingroff - whose excellent histories pepper the Federal Highway Administration's website - “[d]esignation of the urban networks in 1955 and 1957 foreclosed the type of planning that might have defused some of the urban controversies that would surround development of the Interstate Highway Program.”48

In 1999, Robert Fishman of Rutgers University asked leading urban historians, planners, and architects what forces they thought had most shaped the modern American city; topping the list

${ }^{46}$ Andy Cotugno, interview with the author, June 2008

${ }^{47}$ Weingroff, "Designating the Urban Interstates"

${ }^{48}$ Weingroff, "Designating the Urban Interstates" 
were the 1956 Interstate Highway Act and the dominance of the automobile. "More than any other single measure, the 1956 act created the decentralized, automobile-dependent metropolis we know today," Fishman wrote ${ }^{49}$.

${ }^{49}$ Richard F. Weingroff, "The Genie in the Bottle: The Interstate System and Urban Problems, 1939-1957," US Department of Transportation, FHWA:

http://www.tfhrc.gov/pubrds/septoct00/urban.htm 


\subsection{OREGON’S INTERSTATES AND “GENERAL” GLENN JACKSON}

Oregon's first whiff of the coming interstate era arrived in 1943 when Robert Moses was invited to study Portland and propose $\$ 60$ million in public works projects, create $20,000-30,000$ jobs and handle a population newly swollen from the wartime ship- building industry ${ }^{50}$. Moses, since 1918 one of the most powerful public works figures in New York, was known for his love of urban roads, disdain for transit, racist tendencies, and ability to channel and control vast sums of construction money through political tactics and patronage $\mathrm{e}^{51}$.

Moses and his team of engineers and lawyers suggested for Portland everything from parks and playgrounds to freight improvements. Their centerpiece - Moses’ specialty, having cut his teeth diverting money from Franklin Roosevelt's Hudson Valley highway to build his own pet freeway network all over Long Island ${ }^{52}$ - was an arterial plan that included a central loop of freeway, which he called a "thruway." The plan very much set the stage for what was ultimately built: it included a sunken west-side "thruway"; a new Willamette bridge north of the Broadway (“... near Fremont street ...”); a "thruway” north to the Interstate Bridge; a prescription for hundreds of acres of demolition, excavation, and cloverleaf, and links to major highways heading out of town in every direction. It differed in proposing a separate new bridge to Vancouver rather than adding to the first, as was ultimately done in the '50s; in expanding the Ross Island Bridge rather than building a new bridge (the Marquam); in routing the "Foothills Thruway" along Northwest $24^{\text {th }}$ Avenue, around Nob Hill and through Goose Hollow, rather than along $14^{\text {th }}$ and $15^{\text {th }}$ Avenues; and in locating the "Eastside Thruway" not along the Willamette waterfront but several blocks inland ${ }^{53}$.

(Moses' original report was scanned and posted to the Portland Mercury's website in October 2009 by DLCD transportation planner Bob Cortright, after a request from reporter Sarah Mirk in response to reader interest sparked by her article about Portland's "dead freeways."54 So it goes in Oregon.)

Moses' visit was undoubtedly a big deal for Portland. But his day would pass and he would eventually be discredited, even in New York, for his insensitive urban renewal ${ }^{55}$.

At the state level, in 1956 the Oregon State Highway Department (OSHD) and Oregon State Highway Commission (OSHC) stood ready to administer the $\$ 650$ million about to come their way. State departments headed by engineers and citizen commissions to dispense funds were a

\footnotetext{
${ }^{50}$ Robert Moses et al., “Portland Improvement,” New York City, November 1943

${ }^{51}$ Cf. Wikipedia: http://en.wikipedia.org/wiki/Robert_Moses

52 Ibid.

53 Robert Moses, "Portland Improvement"

${ }^{54}$ Sarah Mirk, “The Dead Freeway Society,” Portland Mercury, 9/24/09, pp. 13-15

${ }^{55}$ Cf. Wikipedia: http://en.wikipedia.org/wiki/Jane_Jacobs
} 
legacy of the anti-corruption-minded Good Roads movement. They had, in fact, been required by the 1916 Highway Act for any state wanting to get federal money ${ }^{56}$. Oswald West's original executive commission was thus reformed as a citizen commission in 1917.

Through all the years leading up to the interstate era, Oregon's highway department was considered top-notch; Robert H. "Sam” Baldock was state highway engineer from 1932 to 1956 and served a term as national president of AASHO. Responding to the same congestion noted by the 1930s national survey, Baldock and the OSHD pushed even before the war for an eastern expressway. They had the Banfield built by 1955 , thanks to $\$ 40$ million in state bonds approved in 1952. US 30 through the Columbia Gorge, which would become I-84, had already undergone pre-war upgrades. State engineers also were working on a Portland-Salem Expressway, 26 miles of which had been completed by 1955 and which had only to be upgraded to interstate standards ${ }^{57}$.

Basic route choices for Oregon's 731 miles of non-urban interstate were obvious and made early, by the state, as prescribed in the 1944 Highway Act, although siting would follow. One northsouth and one east-west freeway would be designated I-5 and I-80N (later changed to I-84), respectively. With the state's head start, over half of the key north-south route had been completed by 1961 and it was finished in October 1966. I-84 was finally finished in 1980. Siting was laborious for I-82, the freeway from Hermiston to Washington's Tri-Cities that had been ordered up by the federal government in 1956 to connect to military facilities at Hanford. It was the final piece of Oregon's freeway system when it was completed in $1988^{58}$.

Urban segments “designated” as part of the approved (and funded) 41,000 national miles were few but significant: I-105 from I-5 to downtown Eugene; I-205 through Oregon City, east Portland and Vancouver; I-305 from I-5 through north Salem to its downtown; I-405 to create Portland's Moses-inspired central loop; and I-505 from I-405 through Portland's Northwest industrial area to US 30 west toward Astoria. The Mt. Hood Freeway through Southeast Portland was not part of the original 41,000 miles but, as it was proposed by the city in 1965 to replace the Banfield as the linking segment of the interstate system, it did receive federal approval and funding $^{59}$. Only the I-105, I-205 and I-405 were ever built, along with Highways 26 and 217 in Washington County, which were never interstate segments.

Construction of Oregon's interstates was far along when Glenn Jackson, a self-made millionaire from Medford, was appointed to the Oregon State Highway Commission in 1959; it was half done when Gov. Mark Hatfield made him chair in 1962. By pretty much all accounts, his tenure - lasting until 1979, the year before his death - flew in the face of the Good Roads progressives' and the 1916 federal government's directive that citizen commissions serve as bulwarks against patronage. Jackson, whom Gov. McCall nicknamed “The General,” seemed to craft his power in

\footnotetext{
${ }^{56}$ Bruce E. Seely, “The Beginning of State Highway Administrations: Engineers Take Control,” TR News 245, Jl-Ag 2006, pp. 3-9

${ }^{57}$ George Kramer, “The Interstate Highway System in Oregon: A Historic Overview,” Salem, ODOT, 2004

${ }^{58}$ Ibid.

${ }^{59}$ Ibid.
} 
Robert Moses’ mold. Brent Walth, in his 1994 biography of McCall, Fire at Eden's Gate, had this to say:

Jackson's accomplishments as Highway Commission chair were dramatic. During his tenure the Highway Department spent more than a billion dollars to build [the] interstate freeways and more than eight hundred bridges .... Jackson never escaped questions of conflicts of interest. Many people close to Jackson saw the conflicts, but understood that his political influence guaranteed he would never be held accountable for them. ... [M]any of the fertile tales of his power remain secret, protected by his loyalists, even now ${ }^{60}$.

Maybe so, but those who operated in his sphere tend to have stories and opinions. Recalled Mike Hollern, who served on Jackson's commission from 1975 to 1979 and later served as chair:

He never necessarily believed in the transportation commission [or the] original law setting it up. The commission's primary responsibility was to create policy; under Glenn it never had been done. ... Being on the commission with Glenn meant you weren't too involved in decisions. ... The way he conducted business was: 'Any objections? Approved.' He was not a fan of public meeting laws; he would 'recess' the meeting and light his pipe. He used to have pre-meetings in the director's office; if anyone from the press wanted to be there, they had to get past two secretaries ${ }^{61}$.

Mike Burton, the former Metro chief and also a former state legislator, helped broker a deal to assuage Jackson after Gov. Bob Straub appointed a new OSHD director over his head. Burton said of Jackson, “[h]e never did anything out loud, only behind closed doors .... You don't need to yell very loud if you're controlling the system."62

In the case of the interstates, that control meant authority for siting without much concern for environmental impacts and with little place for public pushback. "Nobody could have contested the freeway location in Yoncalla or Drain,” observed retired transportation planner Craig Greenleaf $^{63}$. Or, as Bill Blosser, former LCDC chair, DLCD director and TPR co-author put it, "Jackson just ran I-5 and I-405 right through the middle of everything.,"64

However, Jackson's OSHC chairmanship, and the development of Oregon's interstates, began in one era and ended in another - with a revolution in between.

\footnotetext{
${ }^{60}$ Brent Walth, Fire at Eden's Gate, Portland: OHS Press, 1994, p. 166

${ }^{61}$ Mike Hollern, telephone interview with the author, August 2009

${ }^{62}$ Mike Burton, interview with the author, April 2008

${ }^{63}$ Craig Greenleaf, interview with the author, May 2008

${ }^{64}$ Bill Blosser, interview with the author, August 2009
} 


\subsection{S WORRIES \& THE DAWN OF ENVIRONMENTALISM}

When did the American environmental movement begin? Some say with John Muir and Teddy Roosevelt, at the turn of the last century. Others say it was with foundation of the Wilderness Society in 1935, publication of Aldo Leopold's A Sand County Almanac in $1949^{65}$, or David Brower's ascension to the Sierra Club presidency in 1952. Consensus, however, would peg it to the 1962 publication of Rachel Carson's book Silent Spring, which became a bestseller and quickly altered domestic public discourse ${ }^{66}$. The election of John F. Kennedy in 1960, inaugurating 12 years of Democratic administrations following eight years of Dwight Eisenhower, did not hurt.

Much Oregon discourse in the 1950s, in step with Moses' visit, was about growth; the state's population increased by $40 \%$ during the decade, and the postwar boom cranked up the economy here as everywhere. Portland, like many cities, planned urban renewal projects to demolish old, ethnic, downtown neighborhoods in favor of new, modern ones. Out of step then, to differing degrees, were two journalists-turned-politicians whose personalities were dominant and whose hearts - also to differing degrees - were with the land.

During the six years from Richard Neuberger's election to the U.S. Senate in 1954 until his death in 1960, he fought high-profile battles, usually involving hydroelectric dams. Historian William Robbins, in his 2004 book Landscapes of Conflict, called Neuberger "an old-style New-Dealer who believed in planning when it was becoming less fashionable ... [but] an ambivalent mix, believing in developing and protecting nature, supporting large public-works projects, and setting aside public lands ...." ${ }^{\text {67 }}$ He loved Hells Canyon on the Snake River and the Deschutes gorge and he fought dams in both places, but it was mostly because they were not homegrown public power projects.

Neuberger's greater significance, though, was captured by fellow newspaperman Steve Forrester in a 1984 article:

By demonstrating that a highly articulate candidate with very liberal ideas could find acceptance with the Oregon electorate, Neuberger shifted the center of Oregon politics. ... Mark Hatfield, onetime Senator and Governor ... [reflected] that “... the Oregon Democratic party seized the liberal perspective, overturning the conservative tradition within its own party. That gave progressives in the Republican party more competition, which turned state politics, Republican and Democratic, more toward the liberal side.”68

\footnotetext{
${ }^{65}$ Aldo Leopold, A Sand County Almanac, Oxford University Press, 1949

${ }^{66}$ Rachel Carson, Silent Spring, New York: Houghton Mifflin, 1962

${ }^{67}$ William G. Robbins, Landscapes of Conflict: The Oregon Story, 1940-2000, Seattle, UW Press, 2004, p. 216

${ }^{68}$ Steve Forrester, "Senator Richard Neuberger: A Man Ahead of His Times,” in Dick Pintarich, Great and Minor Moments in Oregon History, New Oregon Publishers, 2003, pp. 349-361
} 
McCall was just such a progressive Republican. Throughout the '50s, paper-industry waste being dumped into the Willamette River was a growing concern for legislators, yet they proved impotent to stop it. McCall made his name with a hard-hitting 1962 documentary about the problem, Pollution in Paradise. According to Walth, his biographer, “[t]he legislature responded with a bill ... that, for the first time, gave the state the power to shut down a polluting company. ... [This] signaled a change in Oregon politics. For the next twenty years, politicians gave environmental concerns high priority ....” As for McCall, the experience “... was an awakening. What did he offer Oregon that no one else could? He could suddenly answer that now. He could fight for the state itself, its water and air and land." 69

Another thread of conservationist thought and worried action also grew in the ' 50 s in direct response to growth. Along the same urban fringe mentioned by MacDonald and Fairbank, not shining suburbs but haphazard rural-residential real estate development was springing up overnight to meet the boom. Astoundingly, there was vocal concern in the Portland area over automobile-driven suburbanization as early as the '20s, according to Carl Abbott. Depression stalled it, but the war boom brought it back. In 1944, the League of Oregon Cities (LOC) resolved that "sporadic, scattered, and unregulated growth of municipalities and urban fringes has caused tremendous waste in money and resources.”70

In 1947, the Legislature gave counties the authority to appoint planning commissions with the power to zone, but few responded. The following year, the postwar Readjustment and Development Commission reported an exurban “no-man's land where city ordinances do not apply and county courts have no jurisdiction."71 Recreational developments emerged along the coast and in central Oregon.

In 1951, state Agriculture Director E.L. Peterson asked whether "a people [could] multiply and develop in an area rich in natural resources without themselves destroying the resources and natural beauty ...."72 The 1955 Legislature commissioned a statewide study of urban fringes, which revealed the scope of public services problems that existed there ${ }^{73}$; but in the next 10 years, 20\% of Willamette Valley farmland, most of it at cities' fringes but some in farther flung rural subdivisions, was developed ${ }^{74}$.

McCall's election in 1966 finally galvanized action, first a 1967 conference called "The Willamette Valley: What Is Our Future in Land Use," then a legislative interim committee that helped draft Senate Bill 10 directing (not asking) counties to develop land use plans. The law passed in 1969, but eventual land use champion L.B. Day negotiated away companion Senate

${ }^{69}$ Walth, Fire at Eden's Gate, p. 148

${ }^{70}$ Carl Abbott and Margery Post Abbott, “A History of Metro, May 1991,” http://www.oregonmetro.gov/index.cfm/go/by.web/id=2937

${ }^{71}$ Robbins, Landscapes of Conflict, p. 284

72 Ibid., p. 285

${ }^{73}$ University of Oregon, Bureau of Municipal Research and Service, "Problems of the urban fringe. Prepared for the Legislative Interim Committee on Local Government,” 1957

${ }^{74}$ Robbins, Landscapes of Conflict, p. 286 
bills 11,12 , and 13 in the process ${ }^{75}$. What was left proved weak, bringing only laggardly response from counties (and a failed repeal effort). McCall, promising to strengthen it, won reelection in 1970. Finally, in 1973, McCall and key legislators succeeded in passing SB 100, which had considerably greater teeth.

The whole enterprise, the entire era in fact, evolved along with the interstates. Charbonneau, a 477-acre development built by the Benjamin Franklin Savings and Loan next to an I-5 interchange and 15 miles from the nearest suburb, Wilsonville ${ }^{76}$, helped tip the scales in SB 100's favor. Admittedly, the intensive developments that sparse freeway interchanges immediately spawned when the interstates were built - their biggest unintended consequence, added to the intended consequence of suburbanization - were only a trade-out for the continuous commercial development that had characterized non-limited-access highways.

But drawing on the new national environmental and local land-use consciousness, as well as on a broader political awakening that resulted from the civil rights, women's rights and anti-war movements, a special strain of activism - neighborhood-based anti-freeway activism - was evolving. And with it, downtown activism also evolved, business- and housing-focused but responding to suburbanization in the same way that anti-freeway activism responded to suburbanization's major cause.

${ }^{75}$ Arnold Cogan, interview with Ernie Bonner, March 1999, at PlanPDX home: http://www.pdx.edu/usp/planpdxorg-interview-arnold-cogan

${ }^{76}$ Walth, Fire at Eden's Gate, p. 352 


\subsection{FEDERAL URBAN AND TRANSIT POLICY IN THE 1960S}

A funny thing happened on the way to UMTA. In the eight years between the Interstate Act of 1956 and the Urban Mass Transit Act of 1964, freeways were being built, loved by suburban leaders who knew they'd deliver commerce, but equally loved by downtown leaders who also believed they'd deliver commerce and relieve congestion, even while the freeways were helping drain their downtowns of life.

According to Adler, in a 2004 chapter entitled "The Evolution of Federal Transit Policy," national mass transit advocates included at the time of transit's looming demise in the "50s not only those who thought rails were smart, but those whose jobs depended on them. The American Transit Association (ATA, which became the American Public Transit Association, APTA) represented private operators, by then largely bus companies, but also channeled the voices of manufacturers and construction workers. Roads may have meant jobs, but so did transit.

Downtown business leaders, Adler wrote, wanting even more advantage than they thought freeways offered, started trying “... to create regionwide governmental transit agencies that would invest in the types of services and facilities that would enhance the accessibility and reception capacity of the core."77 Suburban leaders successfully blocked many such efforts; that is, until the transit lobby got cagey. ATA leaders encouraged members to seek common cause with downtown merchants, and first succeeded in compelling the creation of no-parkingdowntown days, bus-only lanes, and park-and-ride lots.

Then together, downtown and transit activists succeeded in creating regional transit agencies such as the Los Angeles Metropolitan Transit Authority (LAMTA) in 1951 and the Bay Area Rapid Transit District (BARTD) in 1957.

In a way, their efforts were co-opted and overwhelmed, but at the same time supercharged by a huge political shift. The problems of "urban blight," noted before the war by the freeway advocates, by the 1950s were no longer just a planning problem but a growing human problem; downtowns became a federal, political concern. Beginning in the Republican Eisenhower administration ${ }^{78}$ but mostly following the election of Democrat Kennedy, center-city issues became a huge national focus. And transit champions, led by Congressman Harrison Williams of New Jersey and supported by downtown business and urban revitalization forces, argued successfully that transit planning - and money - were a key component to saving cities ${ }^{79}$.

The results were the 1961 Housing Act, the first federal legislation to deal with urban mass transportation (it offered low-interest loans for service enhancements); then provisions in the 1962 Federal Aid Highway Act mandating urban transportation planning and introducing the

${ }^{77}$ Adler, “The Evolution of Federal Transit Policy,” p. 71

${ }^{78}$ Cf. Edward Weiner, Urban Transportation Planning in the United States: History, Policy and Practice, Springer, 2008, p. 24 (on Sec 701 policy)

${ }^{79}$ Adler, “The Evolution of Federal Transit Policy,” p. 84 
“3C” process (Continuing, Comprehensive, Cooperative); and finally 1964’s Urban Mass Transit Act, appropriating \$375 million in matching funds for transit projects.

Williams' agenda giving transit pride of place in solving urban social ills could not hold. In 1966, the Urban Mass Transit Administration (UMTA) was moved from the Department of Housing and Urban Development to the newly created Department of Transportation, where it became increasingly subject to "rationalization" and "economism," in Adler's analysis ${ }^{80}$ (i.e., to expectations that it demonstrate the benefits relative to the costs of growing transit subsidies). In subsequent years, particularly under the Republican Nixon and Reagan administrations, transit became a political battlefield, even winning a 1986 "Golden Fleece” award from Senator William Proxmire.

But in fits and starts, UMTA began to revitalize mass transit for those urban areas in a position to take advantage. Considering this history, it is not surprising that when anti-freeway activism arose in Portland, it became inextricably bound up with resurgent downtown and mass transit advocacy.

According to Adler, it was an irony that the federal government wanted transportation policy to alter urban form at the same time that local transportation planners were concluding it was too late ${ }^{81}$. This is the point at which Portland diverged permanently from the mainstream, starting or not ceasing - to believe that transportation policy, at least when combined with Oregon's other barrier-smasher, land-use planning, could alter, or at least shape, urban form. Of course Portland still had less area already devoted to decentralized suburbs than most cities, but that was dumb provincial luck.

${ }^{80}$ Adler, “The Evolution of Federal Transit Policy,” pp. 87-95

${ }^{81}$ Ibid., p. 85 


\subsection{RCT, MPC, CRAG, PVMTS, TRI-MET, MSD, METRO, JPACT!}

Nationwide, transit ridership dipped 26\% between 1946 and 1950, and another 28\% by 1954; in Portland, the abysmal figures were $41 \%$ and $34 \%$, with a further $40 \%$ drop to come by 1963 . By the early '50s, Portland's city buses and failing interurbans had ended up in the ownership of a San Francisco company called Portland Transit; neither locals nor city officials liked or trusted them much. As early as 1952 there was talk of public transit ownership ${ }^{82}$.

In 1956, Portland Transit calved off a new and separate company called Rose City Transit (RCT), hoping to get their buses onto suburban lines and convert the interurban rail lines to freight. RCT buried some hatchets with the city council, in line with ATA's agenda. However, the council and new Mayor Terry Schrunk, elected in 1957, were reluctant to extend RCT's franchise. Schrunk and others increasingly believed public ownership was the only way to ensure service. But municipal ownership, put to the voters in 1958 and 1962, failed both times. In 1963, RCT's franchise was extended for 10 years.

Meanwhile, nationally, MacDonald's and Fairbank's constructive (if freeway-inspired) wish for integration of metropolitan regional and transportation planning was coming full circle. Section 701 of the Eisenhower-era Housing Act of 1954 made a start toward funding comprehensive planning aimed at solving urban social problems, initially authorizing \$1 million per year in grants to city and state planning agencies for unified metro-area plans ${ }^{83}$.

According to Abbott, interest in consolidating Portland and Multnomah County government dated back to the 1920s, and thought for creating full metro-area governance went at least back to the 1944 LOC report. The 1956 Legislature asked for a study of "metropolitan government," and in 1957 this resulted in creation of the Portland area's first truly regional body, the Metropolitan Planning Commission (MPC) ${ }^{84}$. The MPC included representatives from the three metropolitan Oregon counties and Clark County in Washington state.

By 1961, due to competition among jurisdictions and an unchecked explosion of special districts, the MPC was in crisis. Rising to the occasion, Abbott says, was "a new generation of leaders comparable to the business and professional men who had initiated Portland-area planning by bringing John Olmsted and Edward Bennett to Portland a half-century earlier." 85 Out in front was the League of Women Voters. Responding to local insistence that 218 urban-area special districts were far too many, the 1963 Legislature created the Portland Metropolitan Study Commission to sort them out.

\footnotetext{
${ }^{82}$ Bianco dissertation, p. 536

${ }^{83}$ Weiner, Urban Transportation Planning in the United States, p. 24

${ }^{84}$ Abbott and Abbott, "A History of Metro, May 1991"

${ }^{85}$ Ibid.
} 
The MPC had been authorized to receive the Section 701 planning grants from the 1954 Housing Act; now the grantor, the federal Housing and Home Finance Agency (HHFA), wanted better small-city representation ${ }^{86}$. So did the cities, according to Abbott; they had "long felt that the four-member board of the Metropolitan Planning Commission gave a cold shoulder to their interests." At the study commission's recommendation, the MPC was replaced in 1966 by the Columbia Region Association of Governments (CRAG), with representatives from each metroarea city and county.

As it happened, that year the new Department of Housing and Urban Development (HUD), successor to HHFA, required that to receive federal funds each metro area must establish a Metropolitan Planning Organization (MPO), representing jurisdictions with at least $90 \%$ of the urban-area population. CRAG, happily, fit the bill. "With threat of federal cutoff of planning and infrastructure dollars, even a reluctant Washington County signed on in October, 1966,” Abbott wrote.

Metro-area transportation planning evolved with governance structure. After Moses’ visit, on through the 1956 Highway Act and until creation of the MPC, regional coordination was limited. In 1959, the year Glenn Jackson joined the Oregon State Highway Commission (OSHC), the commission initiated the Portland-Vancouver Metropolitan Transportation Study (PVMTS). Its mission, according to Abbott ...

... to do area-wide highway planning in compliance with federal government requirements. PVMTS brought together the three counties, Portland, a dozen other cities, the Port of Portland, and the MPC. Clark County and the state of Washington were informal participants. Decisions were made by a Coordinating Committee with the advice of a Technical Advisory Committee. PVMTS employed its own staff early on, but came to rely on consultants and state highway employees ${ }^{87}$.

PVMTS preceded by three years the 1962 Highway Act's mandate for urban transportation planning. It was later observed that the Act, with its " 3 C" requirement for Continuing, Comprehensive planning done Cooperatively by states and local communities, was "the first recognition that there was a role, albeit ill-defined, for public transportation to play in urban areas. ${ }^{, 88}$ But PVMTS, organized with Jackson's OSHC and engineers of the OSHD at its helm, was all about freeways - with hundreds of millions in available federal aid as strong incentive. By 1966 the PVMTS had produced the ambitious, and later infamous, Transportation Plan 1990, and succeeded in getting it adopted by the city of Portland and other local governments. The plan included, in addition to the "committed" Mt. Hood Freeway, "freeway-expressway" routes extending the Mt. Hood to Gresham; from St. Johns to Fairview, Beaverton to Milwaukie, and Lake Oswego to Gladstone; north and west from Beaverton to a soon-to-be-infamous Westside Bypass; and along $39^{\text {th }}$ Avenue and Killingsworth Street in residential east Portland. The PVMATS plan would be dismantled in the early 1970s, thanks to the Governor's Task Force on Transportation.

${ }^{86}$ A. McKay Rich, interview with the author, October 2009

${ }^{87}$ Abbott and Abbott, "A History of Metro, May 1991"

${ }^{88}$ System Design Concepts, “The Cooperative Transportation Planning Process in the Portland Metropolitan Area,” p. 6 
Bianco's extremely well-researched 1994 dissertation paints a picture of the City of Portland's embattled '50s- and '60s-era downtown transportation planning. Her picture opens with an "obituary": "Downtown Business District of City X, last surviving member of a family of City Downtown Business Districts, died yesterday in the City of X, a one-time prominent member of the community" - this from a 1952 Portland city planning commission document, "Bus Transportation in Downtown Portland.,"89

Mass transit, second in attention to freeways and long just left to private companies, began getting attention - including, as mentioned, thoughts about taking it public. Partly due to merchants' fears (the "obituary's" main diagnosis was congestion) and partly due to planners' reaction to freeways, as early as 1960 there were plans on the books in Portland for bus-only lanes, downtown-fringe parking, and later, underground busways. However, these were designed to mesh with downtown advocates' generally preferred alignment for Moses' "Foothills Thruway," by then called I-405 or the Stadium Freeway. They wanted it to travel up Market and Clay streets - a horrifying prospect today, even while we accept the I-405 gash as part of the landscape.

Although their plan was about done, in 1965 the Oregon members of PVMTS agreed to implement “3C" planning and in 1966 they commissioned a Portland-Vancouver Mass Transit Use Study. But their main vision, echoing L.A.'s, was for express busways in freeway rights of way. When their duties were taken over by CRAG in 1967, attention to mass transit remained halfhearted ${ }^{90}$.

On October 14, 1969, after almost a year of ongoing fare and wage disputes and much wrangling over how exactly to go about creating public ownership, the Tri-County Metropolitan Transportation District of Oregon (TriMet) was born. After two failed voter referrals, in the end the mechanism chosen was state legislation. HB 1808 allowed populous local jurisdictions simply to declare transit districts without county ratification or popular vote. Tri-Met received $80 \%$ of the money it needed to purchase RCT's assets from UMTA ${ }^{91}$.

Abbott puts the creation of Tri-Met in the context of broader changes occurring locally and statewide under McCall:

The climax of the PMSC's work came in 1969-70 as part of a burst of concern for planning and environmental protection throughout the state of Oregon. In Salem, mounting concern about maintaining the quality of Oregon's environment brought the state bottle recycling bill, legislation reaffirming the public ownership of Pacific beaches, and planning for a Willamette Greenway. The state's Sanitary Authority changed into a more ambitious Department of Environmental Quality in 1969 ... the same year [as] Senate Bill 10 .... The same years also gave Portland ... [Tri-Met], consolidation of the Portland Commission of Public Docks with the Port of Portland (1970), establishment of a Unified Sewerage Agency for Washington County (1970), creation of the

\footnotetext{
${ }^{89}$ Bianco dissertation, p. 575

${ }^{90}$ Ibid., p. 610

${ }^{91}$ Gregory L. Thompson, "How Portland's Power Brokers Accommodated the Anti-Highway Movement of the Early 1970s: The Decision to Build Light Rail,” Business History Conference, 2006, p. 4
} 
Portland Metropolitan Area Local Government Boundary Commission (1969), and establishment of the Metropolitan Service District (1970).... The Boundary Commission and the Metropolitan Service District ... set the terms for the evolution of regional planning and services in the $1970 \mathrm{~s}^{92}$.

Abbott called MSD “a governmental 'box' which could hold as many service responsibilities as voters or the legislature were willing to assign.” The first was solid waste; later came the Washington Park Zoo. Early on, Tri-Met was considered for inclusion under MSD, but Portland objected and it did not occur.

Throughout the 1970s, CRAG fulfilled planning and transportation planning functions to the extent that it could. However, as a fledgling regional planning organization, CRAG was hampered by imperfect authority, unstable funding, too-extensive membership, and struggles as members began the effort of trying to work collaboratively ${ }^{93}$. The state helped out in 1973 by making membership mandatory, but the following year, responding to new statewide planning rules, CRAG was seen to overstep with its "Columbia-Willamette Region Comprehensive Plan: Discussion Draft," perceived as a "grand regional scheme cooked up by CRAG bureaucrats." ${ }^{\text {" It }}$ was distracted by unsuccessful attempts at city-county consolidation, and in 1976 CRAG survived a statewide ballot measure to abolish all councils of government.

The final act in the long progression to regional government would not come until the formation of Metro in 1979, eliminating CRAG and MSD and combining their functions. At that time, in order to continue meeting federal requirements for regional planning organizations receiving transportation funding, Metro created the Joint Policy Advisory Committee on Transportation, or JPACT. But even before and during the CRAG years, as those who participated still recollect, the evolving ability to work together toward regional consensus about transportation issues with a lot of money at stake - was a shining light ${ }^{95}$.

\footnotetext{
${ }^{92}$ Abbott and Abbott, "A History of Metro, May 1991"

${ }^{93}$ Abbott and Abbott, "A History of Metro, May 1991"

${ }^{94}$ Ibid.

${ }^{95}$ Cf. Rich interview with the author, 2009, and Larry Sprecher interview with the author, May 2007
} 


\subsection{THE ERNIE BONNER INTERVIEWS}

In the realm of writing about planning and civic affairs, somewhere between history as scholarship and history with attitude, lies history that flows straight from the mouths of those who made it. The Terkelesque progressions in such recountings are sometimes those of storytelling, sometimes computer-brained individuals’ magic memories.

Such are transcribed texts from 27 interviews conducted between about 1995 and 2003 by former Portland city planner Ernie Bonner, posted on the website of Portland State University's School of Urban and Public Affairs ${ }^{96}$ (almost twice as many more await transcription).

Bonner, who died in 2004, captured the voices of those who created the transformations Abbott roadmaps above - of Portland from the world of PVMTS to that of Metro and MAX; of Oregon from the realm of Robert Moses and Glenn Jackson to that of Tom McCall and Neil Goldschmidt.

Bits and pieces from Bonner's interviews will appear for years in Oregon planning histories, and they will serve as inspirational models for future Bonners and local Terkels. Giving the texts room to breathe in shorthand history is not very practical, but a not-very-edited sampling to introduce them injects the transformers' voices and provides background music for the chapters to follow:

[Rick Gustafson, former Tri-Met transportation planner and state legislator, and the first Metro chief - recorded February 2003]

Actually, the first council of governments formed in the United States was formed in Salem [under] Kent Matheson, City Manager .... [T] [Te governor who got Eisenhower to form it was Mark Hatfield. Anyway, so these guys [in Portland] put the Columbia Regional Association of Governments together, and in 1967 the Port was made a three-county organization, and so the regionalization was starting. There was an election or legislation in '67 to create a metro-city or something like that, and Roger Martin, representing Lake Oswego, made the mistake of supporting this thing ...

EB: And they killed him?

RG: Well, he didn't lose, but it was a big mistake on his part because there was complete opposition in Lake Oswego to becoming part of Portland, but there was some sort of redoing of the boundaries to regionalize, and as a result of those kinds of initiatives to deal with the regional issues, they proposed forming a Metropolitan Service District as a compromise, bringing the three counties into a regional service district, and the idea was that they'd use this and have county commissioners and the city mayor and all that kind of stuff on the board, and they would regionalize that way. It was going along fine, but some people decided they needed to have a vote to form it, and they needed a vote to fund it. This was in '69, and then Rose City announces that it's going bankrupt, and the transit union goes down to the legislature, and they work up this temporary legislation to save the

${ }^{96}$ http://www.pdx.edu/usp/planpdxorg-interviews-planning-participants 
transit union and Rose City, and they form the Tri-County Metropolitan Transportation District, but it was really in conflict with the Metropolitan Service District, and so it was Connie McCready, who was a legislator at the time, who basically struck the compromise to allow this temporary organization to be created, Tri-Met, and have a provision that if MSD was formed by the voters that MSD would then assume responsibility for Tri-Met. So that's how they put that provision in, and so the two things were formed, and MSD then was put on the ballot and it was passed in May, but then the tax base failed in November. So it was formed, but it had actually no money.

[Earl Blumenauer, Third District congressman and former state legislator - February 2001]

[In 1972] I was first elected to the legislature. There was a big realignment of political activity in Portland at that time. I had worked on campaigns for Tom Walsh and Neil Goldschmidt for City Council in 1970. When Neil was elected to City Hall, one of his executive assistants, Ron Buel, came to me one day in 1971 and said, "You ought to run for the legislature." It was a heady time .... [D] uring the 1970s, Portlanders and Oregonians were further ahead of our time, I think, than we recognized ....

In the State and Federal Affairs committee we worked on the legislation for Senate Bill 100. I was able to guide my first major piece of legislation through that Committee: House Bill 3166, which created Oregon's Transportation Commission. It abolished the Highway Commission (something people thought would never happen) and created a State Transportation Commission [with] the challenge to create a statewide comprehensive multi-modal transportation plan. Now, it took ODOT almost two decades to do it, but it was an important mission and an important statement. My bill mandated that Glenn Jackson be the Chair of the new Commission. I worked very closely with him on the bill, and he was very interested in the broader scope of things. He was a critical ally of Neil Goldschmidt as Mayor, of Tom McCall as Governor, and subsequently, of Bob Straub, who I don't think really got the recognition he deserved as a critical player in all of this. 


\subsection{DOWNTOWN REVITALIZATION AND HARBOR DRIVE}

Arnold Cogan, who would go on to be the first director of the state Department of Land Conservation and Development, recollected in a Bonner interview being hired in 1959 by City of Portland Planning Director Lloyd Keefe. "I had a drafting board right next to a guy named Bob Frasca. And Bob and I worked on a project called Pioneer Courthouse Square - only then we called it the Meier \& Frank parking lot. ... And we worked on the idea - the revolutionary idea of tearing all that parking down and building an open space in downtown Portland. People thought the idea was somewhere between heresy and communism."97

Portland city planners had been active all along; from the bus-lane days and on into the '60s they kept an eye toward professional city and regional planning trends. According to Bob Baldwin, a Multnomah County planner tapped to head up development of Portland's Downtown Plan in 1969, downtown plans had been tried twice before then without success ${ }^{98}$. The growth of suburban retail centers and then, in 1960, the opening of the Lloyd Center mall in east Portland, had downtown merchants frightened. They wanted freeways, they wanted transit, and now they mostly wanted parking. By 1968, the block diagonally across from the Meier \& Frank department store held an unattractive two-story parking lot, and a Tacoma firm was proposing to build a 13-story parking garage ${ }^{99}$. Newly tuned-in citizens protested - loudly ${ }^{100}$.

Shared concern from city council members, especially Lloyd Anderson, led directly to a city partnership with the engineering firm CH2M to try once more to develop a downtown plan. As the plan evolved toward completion, which would come in 1972, both Cogan and Frasca's “Pioneer Square” idea and the ‘50s planners' bus lanes would be included. So would mandatory street-level retail, downtown-edge parking facilities, and a full-on transit mall.

Crucial to the plan, in fact preceding it, was concern over the way to connect the downtown area with the Willamette River waterfront. Since 1942, the year of Moses' visit, an expressway called Harbor Drive had extended the entire length of the riverfront seawall. Soon after taking office in 1967, Governor McCall, who felt connected to the river due to his documentary, Pollution in Paradise, said he wanted Harbor Drive removed ${ }^{101}$. Cogan remembered with horror fresh city plans at the time to create a whole series of off-ramp overpasses from Harbor Drive into downtown. As the governor's chief planner, it was Cogan who got to deliver the news of McCall's intentions to Mayor Schrunk, Commissioner Frank Ivancie and Planning Director

${ }^{97}$ Cogan interview with Ernie Bonner, at PlanPDX

98 Bob Baldwin interview with Ernie Bonner, December 1994, http://www.pdx.edu/usp/planpdxorg-interview-robert-baldwin

99 Dick Ivey interview with Ernie Bonner, January 1995, http://www.pdx.edu/usp/planpdxorginterview-richard-ivey

${ }^{100}$ Betty Merten interview with Ernie Bonner, December 2001, http://www.pdx.edu/usp/planpdxorg-interview-betty-merten

${ }^{101}$ Cogan interview with Ernie Bonner, at PlanPDX 
Keefe. “Their mouths just absolutely dropped. I mean, they were totally stunned,” Cogan remembered ${ }^{102}$.

In response to the city's plans, a group called Riverfront for People formed and began to apply its own pressure to remove Harbor Drive ${ }^{103}$. Despite the group's efforts, media attention and even McCall's expressed preference, both city and state engineers thought closing Harbor Drive would "back cars clear up to Lake Oswego." ${ }^{104}$ A state task force echoed their conclusion; plans not to remove but to widen Harbor Drive proceeded.

Since the expressway was a state highway, the man McCall ultimately had to persuade to remove it was none other than OSHC chair Glenn Jackson. Of all people, Jackson, who had formed an alliance with $\mathrm{McCall}^{105}$, was willing to consider it. According to Dick Ivey, who spearheaded the Downtown Plan partnership for CH2M, “Glenn Jackson liked Harbor Drive. He was basically closing it for his boss. That's exactly what he said to me. He threw up his hands and he said, 'I'm just trying to help the Governor.' That's exactly what he was doing. And he did. Because he could pretty much do anything he wanted to ...."106

Once traffic-flow concerns were solved to Jackson's satisfaction by Ivey and OSHD director Fred Klaboe (improving Front Avenue and creating access from I-405 to the Northwest industrial district for trucks previously using Harbor Drive), it was a done deal. The final decision to remove Harbor Drive was made in 1970; when it was torn out in 1974, there "wasn't a ripple."107 The decision was the first stemming of the automobile tide in Oregon. And the experience was also a major step in what Greg Baldwin (a transportation planner and son of Klaboe's successor, George Baldwin, no relation to Bob Baldwin) would later refer to as “Glenn Jackson's conversion." 108

\footnotetext{
102 Ibid.

103 Ernie Bonner, “PlanPDX.org: Riverfront for People,” http://www.pdx.edu/usp/planpdxorgriverfront-people

${ }^{104}$ Ivey interview with Ernie Bonner, at PlanPDX; Cf. The Preservation Institute, "Removing Freeways, Restoring Cities,” Berkeley, CA:

http://www.preservenet.com/freeways/FreewaysHarbor.html

${ }^{105}$ Walth, Fire at Eden's Gate, p. 168

${ }^{106}$ Ivey interview with Ernie Bonner, at PlanPDX

107 Ibid.

${ }^{108}$ Greg Baldwin interview with Ernie Bonner, February 2003, http://www.pdx.edu/usp/planpdxorg-interview-greg-baldwin
} 


\subsection{NEIL GOLDSCHMIDT, THE GOVERNOR'S TASK FORCE, AND THE MT. HOOD FREEWAY}

On Harbor Drive's heels, the combination of new environmental politics, new urban thinking (and funding), and a generational changing of the guard played out in Portland between 1973 and 1977 as a mighty collision of interests and circumstances. If it were an opera - it was certainly grand enough - it would be called by the name of its second act, The Mt. Hood Freeway Withdrawal; but this would be preceded by Act I: The Governor's Task Force, and followed by Act III: The Light Rail Decision, and Act IV: What To Do With All That Highway Money.

The central drama first deserves mention for its contemporary resonance. Perhaps no event in Oregon planning history has captured the public imagination in quite the same way that the 1974 decision not to build the Mt. Hood Freeway (to “withdraw” it from the interstate system's 41,000 approved miles) has managed to do, at least in the modern era. Creation of the land use planning system in 1973 is an event better known, famously or infamously, statewide. As the campaigns for and against land use Measures 7, 37, and 49 came and went in the 2000s, citizens were repeatedly reminded of SB 100, the LCDC, and Governor McCall.

But as Portland has evolved over the last decade into a growing Mecca - for youth, art, design, money, bicycles, ZipCars, transit, greenness, and the S-word, Sustainability - the Mt. Hood Freeway has taken on a freshly iconic role. It deserves it, and to an extent has maintained it continuously for 35 years, since the Mt. Hood's demise is seen as the defining moment for an activist subculture that surfaces when the fights get big, as they did with an Eastside Freeway uprising in the 1980s and the Westside Bypass defeat in the 1990s, and as they are doing again today with the Columbia River Crossing (CRC).

But there is something more. "Say," said Ron Buel, who fought the Mt. Hood Freeway and is still active today against the CRC, "I just read a Lewis and Clark College undergraduate thesis; it's pretty good." 109 The author was Katelyn Hale and the title is, "Hyperroads and Ghost Ramps: Shifting Urban Priorities and the Death of the Mt. Hood Freeway." 110 One of Hale's sources was Shawn Granton, a "DIY historian” in Hale’s words, knowledgeable about the Mt. Hood. Granton operates "Dead Freeways" bike tours, a fact mentioned in the Sarah Mirk article, “The Dead Freeway Society," "111 that prompted Mercury readers to request copies of Robert Moses' report. Also mentioned in Mirk's article is Val Ballestrem of Portland's Architectural Heritage Center (and an author for PSU's Oregon Encyclopedia), who a couple of years ago wrote his own master's thesis on the Mt. Hood Freeway. Ballestrem is in turn acknowledged in Eliot Fackler's

${ }^{109}$ Ron Buel, telephone interview with the author, July 2009

${ }^{110}$ Katelyn Hale, "Hyperroads and Ghost Ramps: Shifting Urban Priorities and the Death of the Mt. Hood Freeway,” Bachelor's thesis, Lewis and Clark College, Portland, May 2009

111 Sarah Mirk, "The Dead Freeway Society” 
2009 University of Oregon history thesis, "Protesting Portland’s Freeways: Highway Engineering and Citizen Activism in the Interstate Era."112

The Mt. Hood Freeway has wormed its way far into a new generation's culture, including even urban popular culture. Advocates of SB 100 and statewide planning would kill to have their legacy and mythology bear the same cachet among the young. As it is, the statewide program does not quite have such cachet, and this continually puts it at risk. (1000 Friends of Oregon recognizes this; in October 2009, Friends sent out an invitation for nominations of "35 innovators under 35.",113)

The Mt. Hood Freeway’s operatic story really begins back in 1960, before Silent Spring, when another book started its own revolution: Jane Jacobs' The Death and Life of Great American Cities, a critique of 1950s urban renewal policies ${ }^{114}$. As it happened, Jacobs was Robert Moses' most ardent opponent in his drive to dig an I-405-style freeway called the Lower Manhattan Expressway across their New York City borough. She and fellow activists were successful in stopping the project, a last nail in the coffin of Moses' reputation ${ }^{115}$. Jacobs' book was eventually followed by others, including A. Q. Mowbray's 1969 Road to Ruin, a sharp critique of the interstate system ${ }^{116}$; then in 1971, Helen Leavitt's Superhighway, Superhoax, in a similar vein ${ }^{117}$, and Rites of Way by Alan Lupo, about the successful neighborhood revolt against Boston's Inner Harbor freeway ${ }^{118}$; and then by Buel's Dead End in 1972.

James Dunn, in his 1998 book The Automobile, Its Enemies, and the Politics of Mobility, traces the rise of "The Vanguard," his name for the national anti-automobile movement for which Jacobs served as one inspiration ${ }^{119}$. The movement reached Portland in time to remove Harbor Drive and stop the Mt. Hood Freeway - but not in time to have any influence over construction of the Stadium Freeway (I-405), or the segment of I-5 from downtown Portland to Vancouver, WA, which included the Marquam Bridge, the Eastside Freeway, and the "Minnesota" Freeway, excavated as an I-405-style trench through North Portland neighborhoods (along Minnesota Avenue). Neighborhood opposition to the Stadium and the Minnesota freeways, which did surface in the early ' $60 \mathrm{~s}^{120}$, was dismissed. During its design and for years after construction, the Marquam was considered an inappropriate, ugly behemoth, too big by half and far too high.

Topping the list of PVMTS' remaining priorities were the freeways approved to receive 90\% federal funding under the 1956 Interstate Act. These included the I-405, begun in 1967; the I-205

\footnotetext{
112 Eliot Henry Fackler, "Protesting Portland's Freeways: Highway Engineering and Citizen Activism in the Interstate Era,” Master's thesis, University of Oregon, June 2009

113 http://www.friends.org/long-forms/35-under-35

114 Jane Jacobs, The Death and Life of Great American Cities, New York, Random House, Vintage Books, 1960

${ }^{115}$ Wikipedia, Jane Jacobs

116 A. Q. Mowbray, Road to Ruin, Philadelphia: Lippincott, 1969

${ }^{117}$ Helen Leavitt, Superhighway, Superhoax, New York: Ballantine, 1971

118 Alan Lupo, Rites of Way, Little Brown and Company, 1971

${ }^{119}$ Dunn, The Automobile, Its Enemies, and the Politics of Mobility, p. 1

${ }^{120}$ Kramer, "The Interstate Highway System in Oregon: A Historic Overview”
} 
through east Portland, begun in 1968; and the I-505 through the Northwest Portland industrial area, which received federal approval in 1968 but was never built. Portland's other major freeway, the Banfield, was completed before 1956 funding was available. The City, instead of using interstate funds to improve it, in 1965 advanced the idea of getting even more federal dollars to build a brand new freeway along a key PVMTS alignment, out Southeast Powell Boulevard to the I-205, and making this the official downtown interstate link. Between 1965 and 1968, as PVMTS' “Transportation Plan 1990” advanced, the proposal was touted by the City of Portland, CRAG, Multnomah County, and the State of Oregon. In 1969 it finally received their approval, that of the feds, and funding to the tune of $\$ 155$ million $^{121}$. It was called the Mt. Hood Freeway. It has been said that many in far Southeast Portland envisioned it as a "parkway to the hills,” and by 1969 right-of-way purchase had commenced.

For those who wanted the Mt. Hood built, the timing was awful. Neil Goldschmidt, elected city commissioner in 1970, did not come to politics as an anti-freeway, pro-transit activist, but he did believe in the power of neighborhoods and recognized them as his best chance for election as mayor. While canvassing, he sensed the depth of anti-freeway sentiment and ran successfully in 1972 on an anti-freeway platform, with neighborhood power trumping the business interests that unanimously opposed him $^{122}$.

What to do about PVMTS? The 1990 Plan was the region's official transportation plan and its passport to federal dollars. Goldschmidt persuaded McCall to figure out a way to topple the plan, only just adopted in 1971 after 12 years of work. The coup would require both a political eggbeater and sound and defensible rethinking of what sorts of transportation might really work for the urban region. The solution was put into play in May 1973, when McCall announced his Governor's Task Force on Transportation, officially a subset of CRAG. Its 11 members included Goldschmidt, City Commissioner Mildred Schwab, County Commissioners Mel Gordon and James Gleason, and one representative each from the four counties and CRAG. It also included Glenn Jackson and his personal lawyer, Gerard Drummond, who happened to be a friend and campaign leader of Goldschmidt's and would soon join the Tri-Met board ${ }^{123}$.

The task force has, in one sense, been given more ink in subsequent years than its influence warranted. The big action was in Acts II and III, with neighborhood activism and decisions on light rail. But the task force did accomplish several important things. It immediately hired as consultants System Design Concepts (SyDec) of Maryland, whose principals had been involved with the nation's first interstate withdrawal, that of the Inner Harbor freeway in Boston ${ }^{124}$. Together the task force and SyDec systematically dismantled all of the outdated assumptions on

${ }^{121}$ Gregory L. Thompson, “Taming the Neighborhood Revolution: Planners, Power Brokers, and the Birth of Neotraditionalism in Portland, Oregon,” Journal of Planning History 6-3, Ag 2007, pp. 14-47

${ }^{122}$ Thompson, “Taming the Neighborhood Revolution,” p. 226

123 Ibid.

124 Sheldon M. Edner and G. B. Arrington, Jr., "Urban Decision Making for Transportation Investments: Portland’s Light Rail Transit Line,” USDOT Technology Sharing Program, 1985, p. 14 
which PVMTS was based, most notably that mass transit could never be revived. It studied transit corridors, looked at existing rights-of-way, and crunched potential ridership numbers ${ }^{125}$.

But the task force's two biggest contributions were epochal. First, it embodied a completely new ethic that was jelling in the region among a critical mass of young local and newly arrived planners and politicians: that decisions should first be made about urban form, and then about transportation systems - and investments - needed to achieve the form ${ }^{126}$. Second, the ask force created a seat of power to drive the new ethic, and in so doing it brought together Goldschmidt and Jackson. This may be the single defining moment of transportation planning history in Oregon.

Reading two accounts of the era, by Florida State University light-rail scholar Gregory L. Thompson, is like eating rich candy ${ }^{127}$. For his 2004 and 2007 papers, Thompson drew on Bonner's interviews and also reinterviewed, in depth, Bonner's subjects and many others. Thompson's description of interconnections and motivations among the era's brain trust is remarkable. His perspective and conclusions are also those of an outsider seeking to break through outsiders' usual frustrated jealousy of Portland's and Oregon's specialness, in order to find lessons broadly applicable.

Thompson thought to drill into the brains of Drummond and mayoral aide Doug Wright about Goldschmidt and Jackson. Here is what he found:

According to Drummond, Jackson, a road-builder and Republican, grew fond of Goldschmidt, a Democrat and neighborhood activist, because Goldschmidt understood the exercise of power, and Goldschmidt returned the admiration ${ }^{128}$....

... Wright, who closely worked with Jackson, observed [that he] was very respectful of Neil and of the city council and of the direction that the city seemed to be moving ... his attitude was, let's let this young mayor see what he can do ${ }^{129}$.

The relationship also had a dark side. According to Drummond:

A lot of decisions that made projects go forward were decided upon and then the public process occurred to sort of put the gloss of acceptability on them. I attended several breakfasts with Glenn Jackson and Neil Goldschmidt where they decided where they wanted something to head .... ${ }^{130}$

For Thompson, a key lesson was that power brokers will be power brokers, and special Portland was never an exception. Two related lessons, however, were that power brokers such as Goldschmidt can be informed by and represent neighborhood interests, and that this particular

\footnotetext{
125 System Design Concepts, “The Cooperative Transportation Planning Process in the Portland Metropolitan Area”

126 Thompson, “Taming the Neighborhood Revolution,” p. 222

127 Op. cit.

128 Thompson, “Taming the Neighborhood Revolution,” p. 230

129 Ibid.

130 Thompson, “Taming the Neighborhood Revolution,” p. 217
} 
combination of mutually admiring yet disparate power brokers ultimately served Portland very well, creating a "true synthesis of interests." 131

This is not to say that Jackson ever relished losing the Mt. Hood Freeway, but he eventually accepted it - and the fact symbolizes the David-and-Goliath story that Katelyn Hale and other young Portlanders seize on today. Thompson drills into the anti-Mt.-Hood-Freeway activists' circle as well - so does Hale - finding its origins in two small, independent groups that joined forces. The first group sprang directly from the successful work done against Harbor Drive in 1969 by Riverfront for People. One of its founders, Jim Howell, hooked up with Buel, who had come west to work on Goldschmidt's campaign. They named their group Sensible Transportation Options for People, or STOP ${ }^{132}$.

“Isn't that a great acronym? I wish I had thought it up,” said Betty Merten to Ernie Bonner ${ }^{133}$. Merten, who anchored the other group opposed to the Mt. Hood, had led the charge against downtown’s Meier \& Frank parking lot, a fight that galvanized her group to focus on air pollution. Merten's husband, Charlie, an attorney, filed a lawsuit asserting that required processes had not been followed in selecting the Mt. Hood's corridor. Together they named their group the Southeast Legal Defense Fund. By the time the groups joined forces under the STOP banner, leaders included Elsa Coleman and Steve Schell ${ }^{134}$.

STOP reacted plain and simple to the devastation that the Mt. Hood Freeway would wreak upon its members' corner of Portland. A picture is worth a thousand words: the '60s-vintage virtual rendering on Hale's cover page shows a giant Marquam Bridge doubled in width, multiple ramps with a malevolent science-fiction look, and the freeway itself an enormous white swath where several east-west streets exist today. A total of 1,679 houses would have been demolished ${ }^{135}$.

STOP had Goldschmidt; with the task force it had him positioned to influence Jackson. It would need both. Proponents of the Mt. Hood, led by City Commissioner Ivancie, County Commissioner Dan Mosee, and multiple east-county interests, wanted to put a referral on the ballot. Polls showed they would win 10 to 1 if that happened ${ }^{136}$. But STOP had four other powerful allies: NEPA, SOM, the 1973 Highway Act, and Don Clark.

NEPA, the National Environmental Policy Act, was passed by Congress in 1969 following five years of debate about environmental impacts from large-scale development projects. Concern over the effect of roads, particularly freeways, had forced action from the federal Bureau of Public Roads not long after publication of Silent Spring. In the mid-'60s, the agency required evaluation of alternative routes, and the 1968 Highway Act prescribed public hearings for urban freeways as well as consideration of economic, social, and environmental effects of routing ${ }^{137}$.

\footnotetext{
${ }^{131}$ Ibid., p. 241

132 Ibid. p. 225; Merten interview with Ernie Bonner, at PlanPDX

${ }^{133}$ Merten interview with Bonner

134 Ibid.

135 Hale, “Hyperroads and Ghost Ramps,” p. 39

136 Thompson, “Taming the Neighborhood Revolution,” p. 231

${ }^{137}$ Richard Weingroff, “Addressing the Quiet Crisis: Origins of the National Environmental
} 
NEPA, introduced by Washington Sen. Henry Jackson in the first days of a reluctant Nixon administration, expanded review into something taken for granted today: the Environmental Impact Statement (EIS).

The Oregon Department of Transportation, or ODOT (renamed and reorganized from the Oregon State Highway Department in 1969), was responsible for the Mt. Hood's EIS, and despite strong sentiment within the department in favor of the freeway, Director George Baldwin took the task seriously $^{138}$. ODOT retained the firm Skidmore, Owings and Merrill (SOM) to conduct it. "An architectural firm!” said Baldwin, who worked for SOM on the Mt. Hood EIS ${ }^{139}$. The project was "under a discipline that took account of more aspects of a city" compared to engineers, Baldwin observed.

"NEPA had a huge impact on the Mt. Hood Freeway," Baldwin continued. The SOM team "looked 1.5 miles on either side, looked at home prices. How many [would] change to rentals? What would happen if you did transit? We insisted that if there was an interchange, there had to be a benefit. NEPA said that; SB 100 did also. ... If you build a transportation system, you have to see how it enriches the community.” SOM analysts began to see that the Mt. Hood did not.

The firm's influence went further. When Thompson did some drilling into the head of Ernie Munch, an SOM team member who would later go to work for Goldschmidt, he learned that Munch and others had leaked negative findings to the City and the activists ${ }^{140}$. ODOT engineers became belligerent. "It was a crazy, paranoid time," said George Crandall, another SOM team member. "One ODOT engineer would write sarcastic remarks all over our work; it was not rational. There is kind of an untold story. The positives just weren't there. The freeway dumping into downtown? Impossible." 141 NEPA was trashing the Mt. Hood - as it might have done many earlier freeways had it been given the chance.

In 1973, with the national interstate system nearly complete and urban anti-freeway pressure peaking, the federal government passed a new Highway Act allowing states to cancel unpopular freeways and keep the money for use on other freeways - or for transit projects. The passage date was August 1973, three months after the task force convened. The effect was transformative; without this "interstate transfer" provision, Thompson believes, the Mt. Hood would have ended up being built ${ }^{142}$ : what local government could justify foregoing \$155 million earmarked for contractors? The act also allowed, for the first time, expenditure of Highway Trust Fund money on transit projects. Baldwin recalls a 1972 memo with information from U.S. Secretary of Transportation John A. Volpe anticipating the shift. "In our SOM office, we'd get the policies first," Baldwin said; the memo caused the state to ask SOM to include a transit-only

Policy Act of 1969,” US Department of Transportation, FHWA:

http://www.fhwa.dot.gov/highwayhistory/nepa/index.cfm

${ }^{138}$ Greg Baldwin, telephone interview with the author, June 2009

139 Ibid.

140 Thompson, “Taming the Neighborhood Revolution,” p. 227

${ }^{141}$ George Crandall, telephone interview with the author, May 2009

142 Thompson, “Taming the Neighborhood Revolution,” p. 227 
option in its EIS ${ }^{143}$. Finally, the 1973 Act mandated that states obtain local approval for urban freeways. Portland could now trump ODOT.

So could Multnomah County, and the chair of its Board of Commissioners, Don Clark, was on board to do so. Clark was an early proponent of the land-use-first, transportation-planningsecond ethic. Along with a local booster named Larry Griffith, he was among the first in Portland to espouse European-style light rail. Clark came to abhor the impacts of modern freeway building, going so far as to use his board coalition to block completion of I-205 across his Multnomah County jurisdiction ${ }^{144}$.

Shortly after SOM completed its report to ODOT in December 1973, finding that negatives outweighed positives for building the Mt. Hood, the Governor's Task Force recommended rejecting all alternatives that required demolition of any houses. At this point, Buel went to Clark asking that the County be the first to rescind its approval of the freeway since Goldschmidt felt too politically vulnerable to do so ${ }^{145}$ (despite the task force's decision). In February 1974, Charlie Merten won his case against the Mt. Hood in federal court, blocking the state from proceeding in any case. In the same month, the County Commission rescinded its previous approval, and that summer the City followed suit. At the County hearing, as Thompson recounts it:

[Clark] did not know if the county had the legal authority [but] realized that he indeed had that power when, as the meeting was about to begin, Jackson walked into the chamber accompanied by George Baldwin, director of the ODOT ... [W]itness after witness spoke against the freeway, many with damaging information from the EIS. Jackson spoke but only to say that the federal interstate money ... had better be kept in the region. When the meeting broke up ... he turned to me and he says, "Clark, I hope you know what you're doing.","146

By the end of the year, Governor McCall, near the end of his administration, notified the federal government that the Mt. Hood Freeway was to be deleted from the interstate system. The effort to mount a ballot measure or seek referral from the legislature never materialized; opposition would continue, but would fade once it was definite that money and jobs would indeed remain in Oregon. The stage was set for final acts of the Mt. Hood drama: the long and winding road leading to the choice of light rail, as opposed to that also-ran from L.A., busways - which even Goldschmidt initially favored; final resolution of Clark's hatred of the I-205, in a deal with Glenn Jackson; the '70s Portland anti-freeway movement's last stand in withdrawing the I-505; and the region's financial dance of joy over its fortune in coming into hundreds of millions of dollars to spend on transit and, as it turned out, other road projects.

Thompson's assessment is that although the moves in withdrawing the Mt. Hood were made by power brokers, the activist uprising led by STOP influenced both them and their bureaucracies. And, the big revolution brought about by the withdrawal was local government regaining control of its own transportation planning and future. The Mt. Hood was dead; so was the interstate era.

143 Crandall, telephone interview

144 Thompson, “Taming the Neighborhood Revolution,” p. 226

145 Ibid., p. 228

${ }^{146}$ Ibid., pp. 230-231 


\subsection{SENATE BILL 100 AND GOAL 12}

The defeat of the Mt. Hood Freeway, in Portland, and the political events leading up to it, directly affected land use and transportation planning at the state level. As the Department of Land Conservation and Development's (DLCD's) website puts it, “[t]his was a transformational event that mark[ed] the end of freeway construction and the beginning of serious efforts to integrate land use and transportation planning. At the time, it was a revolutionary change; it adopted an entirely untried solution and led to subsequent efforts to use transportation investments to achieve land use objectives."147

A central point of connection between activists and officials in Portland and those in Salem was the state-level team convened to draft land use planning goals, as prescribed by SB 100. Greg Baldwin remembered this as a key connection, but also as only one in a network of connections. He described the nature of communication within the transportation planning community at the time:

There were a lot of coincidental things; a lot complementary. [Contact] was instructive, not strategic; there was crossover. The CRAG board met every two weeks; it had Neil Goldschmidt, who had multiple roles; my father [George Baldwin, state Department of Transportation director] was on there [too]. It's not surprising there'd be coordination with what was undertaken by staff at ODOT. L.B. Day [the first Land Conservation and Development Commission (LCDC) chair] was close to all the people on the Oregon Transportation Commission. Glenn Jackson saw my father every other day. ... There was lots of casual if not formal communication. Steve [Schell] was on STOP and developing goals and guidelines for the LCDC and trying landmark cases in the law that was emerging. Steve founded a small firm, EDI, with Russ Beaton and Glen O’Dell. Russ chaired a goals committee; they were all writing the goals; information flowed freely. ${ }^{148}$

Arnold Cogan, who had been chosen by Governor Tom McCall as the state's first planning director $^{149}$, was now chosen by the just-convened LCDC as director of the new state planning office, the DLCD. Among the statutory provisions of SB100, the commission was charged with crafting and adopting, by the end of 1974, statewide planning "Goals" in accord with SB 100. It fell to Cogan and his staff to co-create the process and the substance of the goals. Their scheme for doing so was to be highly input-based. "I rented two vans and we outfitted these vans for workshops and we went on the road," Cogan said. "For a whole year, we went on the road. ... We said that this program was going to be built from the bottom up ... I don't know how many times I made that speech.”" ${ }^{50}$ The effort, according to Cogan, involved three mailings to 100,000 randomly selected citizens ${ }^{151}$, and three sets of meetings, the first two in 35 different towns, the final set consisting of 10 regional public hearings required by SB100. The statewide meetings would become a key moment in the often-told story of the program's creation.

\footnotetext{
147 http://www.oregon.gov/LCD/history.shtml\#1973_1979

148 Greg Baldwin, telephone interview with the author

${ }^{149}$ Not his title, but his function

${ }^{150}$ Cogan, interview with Ernie Bonner

${ }^{151}$ Ibid.
} 
Asked by Bonner whether DLCD staff went out the first time with draft language in place, Cogan replied, “[w]e didn't have any drafts ... just the language of Senate Bill 100.” For transportation, as for most of the goals, much time and ink had been spent on issues and policy, at least since the drafting of Senate Bill 10 in 1969. Yet SB-100's topic-specific language was as sparse as could be:

[SECTION 48] 215.515. (1) Comprehensive physical planning, adopted by the commission prior to the expiration of one year ... should provide guidance for physical development within the state responsive to economic development, human resource development, natural resource development and regional and metropolitan area development. ... The plans should set a pattern upon which state agencies and local government may base their programs and local area plans. Goals for comprehensive physical planning [include] ...

[(6)] (g) To provide and encourage a safe, convenient and economic transportation system including all modes of transportation: Air, water, rail, highway and mass transit, and recognizing differences in the social costs in the various modes of transportation.

This was, in fact, the same transportation language that had been included in SB 10. It became the starting point for creation of Transportation Goal 12, one of 19 Goals that would function as the new program's constitution, with the first LCDC serving as the constitution's framers, aided by DLCD. SB 100 passed and was signed by McCall on May 29, 1973. The Governor's Task Force had been announced 26 days earlier. The LCDC, under Day, convened in October and crafted goals over the next 14 months; the Governor's Task Force's final report, dated January 1975, followed completion of the goals by days or weeks. The two policy- (and history-) making bodies existed at precisely the same moment in time.

Although both channeled debates that had preceded them for years, by early 1974, as the LCDC began its work in earnest, the task force was far along with its own and had, in preparation for recommending withdrawal of the Mt. Hood, already crafted the basis for multimodal transportation planning, substituting transit assumptions for PVMATS' highway-centric data.

Details are incomplete concerning the evolution of statewide Goal 12, from a sentence in SB100; through "crossover" from the evolving task force and CRAG efforts; to DLCD iterations appropriate to urban and rural areas, presented in 35 towns; and then to the final version adopted in December 1974. More details are certainly extant.

Documents in the state archives and in possession of retired planner Jim Knight, who staffed the goal-writing process along with Brent Lake, Walt McCollum and Herb Riley, outline the progression. A memo prepared for the June 28, 1974 commission meeting shows draft goal development steps proposed following the first round of outreach (in Cogan's vans). DLCD staff proposed putting off much of goal and guideline development until 1975. One sample goal attached was the Transportation goal, which read in part:

Oregon's transportation system, to be truly intermodal [shall/should] be structured to promote the maximum degree of fiscal and program flexibility to guarantee that the allocation of transportation resources shall proceed in a manner which will achieve the greatest return on the public's investment. 
The Oregon Transportation Commission, in full accordance with state law, [shall/should] develop and maintain a state transportation policy and comprehensive long-range plan for a multi-modal transportation system in the state ...

ODOT, special transportation districts and state, county and city planning agencies [shall/should] demonstrate in their plans and programs acknowledgement that transportation exerts a significant influence over the air, water, noise and visual environment [and] strongly defines the character and direction of an area's land use patterns ... ${ }^{152}$

The draft unified transportation goal (incorporating both highways and mass transit) was wordy and vague, running to nearly six double-spaced pages. Cogan has said that advisory committees wrote most of the language ${ }^{153}$. Steve Schell, serving as LCDC's vice-chair under Day, remembers staff being responsible. "Planners are compromisers; I was in law and interested in what it would change," he said ${ }^{154}$. Schell remembers what happened at a subsequent summer 1974 commission meeting (perhaps on June 28 but probably later):

It was a knock-down, drag-out meeting. We'd been out and toured the state; the [LCDC] members were in on numerous meetings. Staff came back with general goals; I, along with [fellow commissioners] Paul Rudy and Dorothy Anderson, said, these are too generalized! L.B. said, use the goals from 1969. I said, they haven’t worked! ... We started to debate this. After two hours, I leaned to L.B. and said, you have the votes [to proceed with the draft goals], but he said, no, keep talking. After five or six hours, we decided to appoint committees [to strengthen the goals]. ${ }^{155}$

A draft of goals prepared in time for the commission's July 26 meeting split transportation into two components, freeways and mass transit, and kept each of the two resulting goals (Nos. 10 and 11) to barely more than a page. An excerpt from the freeways goal:

Goal Subject \#10 - Freeways and Major Highways ... are vital to growth and development [but] can stimulate uncontrolled growth and urban sprawl ... There has been an overwhelming reliance on the automobile and lack of adequate alternative means of transportation in urban areas. Federal funding has placed an emphasis on development of interstate and intercity highways ...

OVERALL GOAL: The location and development of freeways and major highways ... guided by transportation plans which consider use of automobile, mass transit and other modes, which have been integrated with comprehensive land use plans, and which have been coordinated with state and local economic, environmental, and energy programs ...

The length was gone, but the vagueness remained. The commission considered a slightly changed version at its meeting on August 27. Meanwhile, according to Schell, Cogan and Day had published a list of potential goal advisory committee members, to which Schell objected. "I said, you're appointing state agency heads! We need people who'll make changes. They said, if

\footnotetext{
152 "LCDC Retreat and Workshop: Goals and Guidelines Session,” no date but refers to 6/29/74 meeting ${ }^{153}$ Cogan interview with Ernie Bonner

${ }^{154}$ Steve Schell, telephone interview with the author, December 2009

${ }^{155}$ Steve Schell, telephone interview with the author, May 2009
} 
you're so smart, you appoint the committees.”156 Not long after the August 27 meeting, Schell initiated exactly that; in an August 30 memo to fellow commissioners he wrote:

I have some strong misgivings about going to the public with this set of goals ... [E]ven from my limited knowledge of a few of these subjects, there is very little attention to either the actual problems or the possible solutions. ... It appears that there is neither a clear understanding of the problem or of the facts involved or of consequences of that goal. ... [I propose] that a technical committee be appointed for each of the goal subject areas ... with instructions to report back ... not later than October 1, $1974 .^{157}$

Schell proposed one-page goals, "for use in public workshops," each of which would "(a) State the problems; (b) Provide three alternative solutions based on different balances between conservation and development; (c) State relevant facts and environmental, economic, social and energy consequences.” It is not clear which versions of goals were taken out for the second round of meetings.

Schell proposed five names for each of two transportation technical committees, including a combination of ODOT, STOP, agency and private-sector people. Buel was proposed; so were Blumenauer and Greg Baldwin ${ }^{158}$.

But in the event, the process started off on a considerably different tack. Perhaps in response to a September 6 memo from the Association of Oregon Counties, proposing its own names for the technical committees, a separate, overarching Technical Advisory Coordinating Committee (TACC) was first formed. It consisted of 24 members representing with precise equality state and local government, environmental and economic interests ${ }^{159}$.

For a September 18 TACC meeting in Portland, Schell refined his goal-by-goal "Suggested Technical Committees." The TACC divided itself into six subcommittees, each responsible for two goals. In a September 24 memo to the finally selected members of the technical committees (in this instance called Advisory Resource People), Cogan thanked them and told them they'd be consulted, by the TACC, "to obtain diverse choices in each of the eleven goal areas."

The TACC's and the technical committees' work, conducted over the next two weeks, led to deep changes in the goals. "Earlier this Fall," said a November 1 memo (from Schell this time), "technical committees were established to draft additional problem statements and goal alternatives. ... [T] [Tis work was largely concluded in early October, [and] the Commission, at its October 11 meeting, made significant changes in the goals [sic] subjects.” The changes meant the technical committees had to be reconvened in order to ratify them ${ }^{160}$.

\footnotetext{
156 Ibid.

${ }^{157}$ Memorandum from Steven R. Schell to LCDC, dated 8/30/74

158 Proposed were Ron Buel, Greg Baldwin, Francis Diemoz, Norm Howard, and Fred Clayboe [sic], for Freeways and Major Highways; and Elsa Coleman, Dennis Moore, Bill Roberts, and Earl Blumenauer, for Urban Mass Transit.

${ }^{159}$ Memorandum from Arnold Cogan to Advisory Resource People, dated 9/24/74

${ }^{160}$ Letter from Steve Schell to Technical Committee Members, dated 11/1/74
} 
Time was growing short. According to Schell's memo, at the October 11 meeting the commission saw both the first-round TACs' work and "initial results of Round II of the citizen workshops." They reduced the number of goals from 11 to 10, combining the two transportation goals, and then staff "strengthened the ... goals by incorporating significant portions of the TAC work. On October 24, the LCDC approved the revised [goals] and directed the staff to proceed with the printing and distribution ... for the upcoming statewide public hearings scheduled for middle and late November."

In a blitz of meetings with the reconvened - and expanded - TACs (the groups' final configuration appeared in a November 5 memo from Knight and Lake ${ }^{162}$ ), the goals got their final imprimatur from the broadest possible representation of interests. It is not clear how much of the third-round changes came from the original TACs (or the TACC), how much from the public, and how much from Schell, the commission, and DLCD staff. But the goals were much evolved for final public hearings and for adoption on December 27.

Goal 12 in its final form was just over two single-spaced pages. It began with the overall goal, "to provide and encourage a safe, convenient and economic transportation system." This was followed with the words, "A transportation plan shall," with nine specific prescriptions for local comprehensive plans, which would be required under SB 100. Next came five definitions and, finally, six planning guidelines and four implementation guidelines peppered with "should"s instead of "shall”s but with great specificity for local plan developers.

"Steve Schell was the driver," Knight said of the technical committees. "He wanted buy-in from opinion leaders .... The committees had very successful people with opposing strong views. ... Steve was cerebral and L.B. was political; he cared less about the fine points. Steve had the intellect to see the implications."

Cogan, architect of the statewide outreach, got caught crosswise to what he later described as Day's efforts to "make sure that he had solidified his control of things."164 Cogan lost his job in December or January, and left in February 1975. Adoption of the goals occurred on December 27, days before the end of McCall's second and final term as governor. The beginnings of the goals’ implementation, and Cogan's departure, would occur in the first days of the new administration of Democrat Robert Straub. Knight remembers McCall and Straub sitting shoulder to shoulder at the historic December 27 goal-adoption hearing.

\footnotetext{
161 Schell 8/30/74 memorandum

162 Memorandum from Brent Lake and Jim Knight to Staff, dated 11/5/74; Transportation Technical Advisory Committee members included George Baldwin, Fred Dyer, Mel Gordon, Jack Kalinoski, Dennis Moore, Charles Merten, Elsa Coleman, Dr. Larry Griffith, Ernie Munch, Judge Earle C. Misener, and Lloyd Anderson

163 James Knight, interview with the author, July 2009

${ }^{164}$ Cogan interview with Ernie Bonner, at PlanPDX
} 


\section{BIBLIOGRAPHY}

\section{INTERVIEWS CITED}

Baldwin, Robert, interview with Ernie Bonner, December 1994, at PlanPDX website, http://www.pdx.edu/usp/planpdxorg-interview-robert-baldwin

Baldwin, Greg, interview with Ernie Bonner, February 2003, at PlanPDX website, http://www.pdx.edu/usp/planpdxorg-interview-greg-baldwin

Baldwin, Greg, transportation planner and former Skidmore, Owings and Merrill engineer, telephone interview with the author, June 2009

Blosser, William, planning engineer; former chair, Oregon Land Conservation and Development Commission; former director, Oregon Department of Land Conservation and Development; co-author, Oregon Transportation Rule, interview with the author, downtown Portland, August 2009

Buel, Ronald, transportation activist; co-founder, Sensible Transportation Options for People; author, Dead End, telephone interview with the author, July 2009

Burton, Michael, former Oregon state representative, former Metro executive, interviews with the author at Portland State University, April/May 2008

Cogan, Arnold, interview with Ernie Bonner, March 1999, at PlanPDX website, http://www.pdx.edu/usp/planpdxorg-interview-arnold-cogan

Cotugno, Andrew, Metro planning director, interviews with the author at Metro offices, June 2008, October 2009

Crandall, George, former Skidmore, Owings and Merrill engineer, telephone interview with the author, May 2009

Greenleaf, Craig, former deputy director, Transportation Development Division, Oregon Department of Transportation; former acting director, Oregon Department of Land Conservation and Development, interviews with the author at Greenleaf home, Happy Valley, Oregon, May 2008 and August 2009

Hollern, Michael, former member and chair, Oregon Transportation Commission, telephone interviews with the author, August 2009

Ivey, Richard, interview with Ernie Bonner, January 1995, at PlanPDX website, http://www.pdx.edu/usp/planpdxorg-interview-richard-ivey

Knight, James, former staff planner, Oregon Department of Land Conservation and Development, interview with the author, downtown Salem, July 2009

Luke, Dennis, chair, Deschutes County Commission, interview with the author at Deschutes County offices, June 2009

Merten, Betty, interview with Ernie Bonner, December 2001, at PlanPDX website, http://www.pdx.edu/usp/planpdxorg-interview-betty-merten 
Rich, A. McKay, former chair, Metropolitan Planning Commission; former director, Metropolitan Study Commission, telephone interview with the author, October 2009

Schell, Steven, attorney at law, co-founder, Sensible Transportation Options for People; former vice-chair, Oregon Land Conservation and Development Commission, telephone interviews with the author, May and October 2009

Sprecher, Laurence, former Beaverton city manager, telephone interview with the author, May 2007

\section{REFERENCES CITED}

Abbott, Carl, and Margery Post Abbott, 1991, “A History of Metro, May 1991,” at Metro website, http://www.oregonmetro.gov/index.cfm/go/by.web/id=2937

Adler, Sy, 1991, "The Transformation of the Pacific Electric Railway: Bradford Snell, Roger Rabbit, and the Politics of Transportation in Los Angeles,” Urban Affairs Quarterly 27-1, Se, pp. 51-86

---- 1993, “The Evolution of Federal Transit Policy,” in Martin A. Melosi and Martin V. Melosi, Urban Public Policy, Penn State, pp. 69-99

Bianco, Martha J., 1994, "Private Profit Versus Public Service: Competing Demands in Urban Transportation History and Policy, Portland, Oregon, 1872-1970,” PhD dissertation, Portland State University, 731 pp

---- 1998, “Kennedy, 60 Minutes, and Roger Rabbit: Understanding Conspiracy Theory Explanations of the Decline of Urban Mass Transit,” PSU Center for Urban Studies, Discussion Paper 98-11, November, 21 pp

Bianco, Martha J. and Sy Adler, 1998, “The Politics of Implementation,” PSU Center for Urban Studies, November 1998, 25 pp

Bonner, Ernie, PlanPDX.org, 2000, "Planning in the 70s,” Interviews, at PlanPDX website, http://www.pdx.edu/usp/planpdxorg-interviews-planning-participants

---- PlanPDX.org, 2000, “Riverfront for People,” at PlanPDX website, http://www.pdx.edu/usp/planpdxorgriverfront-people

Buel, Ronald A., 1972, Dead End: The Automobile in Mass Transportation - How We Got Where We Are, How We Can Turn Around, Englewood Cliffs, NJ: Prentice Hall, 231 pp

Blume, David, 2007, Alcohol Can Be A Gas!, Soquel, CA: The International Institute for Ecological Agriculture, $530 \mathrm{pp}$

Carinci, Justin, 2009, “State studying WES possibilities,” Daily Journal of Commerce online, 7/7/09

Carson, Rachel, 1962, Silent Spring, New York: Houghton Mifflin

Cliff, Patrick, 2009, “Planning a route to regional transit,” The Bend Bulletin, 8/10/09

Columbia Region Association of Governments (CRAG), 1974, “CRAG Transportation Goal adopted March 15, 1974” (Oregon State Archives, LCDC collection, 7/19/74)

Conti, John, 2009, “U.S. Greenhouse Gas Emissions in the Transportation Sector,” Energy Information Administration, U.S. Department of Energy, July 
Cornett, William, 2009, “Vaughn Street Park and the Great Baseball War of 1903,” Portland, Oregon, Northwest Examiner, October, pp. 22-3

Deschutes County, Oregon, n.d., “County Road Establishments by Year,” at Deschutes County website, www.co.deschutes.or.us, Road Reports

Dunn, James A., 1998, Driving Forces: The Automobile, Its Enemies, and the Politics of Mobility, Washington, DC: The Brookings Institution, $230 \mathrm{pp}$

Edner, Sheldon M. and G. B. Arrington, Jr., 1985, "Urban Decision Making for Transportation Investments: Portland’s Light Rail Transit Line,” USDOT Technology Sharing Program, 116 pp

Fackler, Eliot Henry, 2009, "Protesting Portland's Freeways: Highway Engineering and Citizen Activism in the Interstate Era,” Master’s thesis, University of Oregon, June

Forrester, Steve, 2003, "Senator Richard Neuberger: A Man Ahead of His Times," in Dick Pintarich, Great and Minor Moments in Oregon History, Portland: New Oregon Publishers, pp. 349-361

Garrison, William L. and David M. Levinson, 2006, The Transportation Experience, Oxford University, 457 pp

Graham, Matthew, 2009, “Ardenwald neighborhood livid about light-rail bridge,” Portland, The Clackamas Review," 6/3/09

Hale, Katelyn, 2009, "Hyperroads and Ghost Ramps: Shifting Urban Priorities and the Death of the Mt. Hood Freeway,” Bachelor’s thesis, Lewis and Clark College, Portland, May, 59 pp

Hsuan, Amy, 2009, “Forest of Fuel,” Portland, The Oregonian, 9/6/09, p. D1

Jacobs, Jane, 1960, The Death and Life of Great American Cities, New York: Random House, Vintage Books

Kay, Jane Holtz, 1997, Asphalt Nation, Berkeley: UC Press, 418 pp

Kramer, George, 2004, “The Interstate Highway System in Oregon: A Historic Overview,” Salem, ODOT, 119 pp

Kunstler, James Howard, 1994, The Geography of Nowhere, New York: Touchstone, 303 pp

LaHood, Raymond, 2009, speech at Oregon-made streetcar launch event, South waterfront, Portland, 6/29/09

Learn, Scott, 2009, “Recession, new doubts take bloom off biofuels,” Portland, The Oregonian, 6/7/09, p. A1

Leavitt, Helen, 1971, Superhighway, Superhoax, New York: Ballantine

Leopold, Aldo, 1949, A Sand County Almanac, Oxford University Press

Lupo, Alan, 1971, Rites of Way, Little Brown and Company

Mapes, Jeff, 2009, Pedaling Revolution, Corvallis: OSU Press, 288 pp

Mirk, Sarah, 2009, “The Dead Freeway Society,” Portland Mercury, 9/24/09, pp. 13-15

Moses, Robert et al., 1943, “Portland Improvement,” New York City, November

Mowbray, A. Q., 1969, Road to Ruin, Philadelphia: Lippincott

One Thousand Friends of Oregon, 2009, invitation to nominate, at Friends website, http://www.friends.org/longforms/35-under-35 
Oregon Department of Land Conservation and Development, n.d., history of Oregon land use planning, at website http://www.oregon.gov/LCD/history.shtml\#1973_1979

---- , 1974, “LCDC Retreat and Workshop: Goals and Guidelines Session,” no date but refers to 6/29/74 LCDC meeting (James Knight collection)

---- , 1974, Memorandum from Arnold Cogan to Advisory Resource People, dated 9/24/74 (James Knight collection)

---- , 1974, Letter from Steve Schell to Technical Committee Members, dated 11/1/74 (James Knight collection)

---- , 1974, Memorandum from Brent Lake and Jim Knight to Staff, dated 11/5/74

---- , 1974, Memorandum from Steven R. Schell to LCDC, dated 8/30/74 (State of Oregon archive, DLCD collection)

Oregon Department of Transportation (ODOT), n.d., “Oregon on the Move, a history of Oregon's transportation systems," $164 \mathrm{pp}$

---- , 2007, “Oregon’s Mileage Fee Concept and Road User Fee Pilot Program,” 92 pp

Oregonian editorial board, 2008, "No way to run a railroad,” 5/1/08

Paine, Chris et al, 2006, “Who Killed the Electric Car?” (documentary film, on DVD)

Pintarich, Dick, 2003, “The Rise and Fall of Oregon’s Electrics,” in Pintarich, Great and Minor Moments in Oregon History, New Oregon Publishers, pp. 190-202

Portland Vintage Trolleys website, www.vintagetrolleys.com

Preservation Institute, n.d., "Removing Freeways, Restoring Cities,” at Preservation Institute website, http://www.preservenet.com/freeways/FreewaysHarbor.html (Berkeley, CA)

Redden, Jim, 2009, “Cities Fight to Avoid Being Left at Station,” The Portland Tribune, 8/20/09, p. 1

Robbins, William G., 2004, Landscapes of Conflict: The Oregon Story, 1940-2000, Seattle: UW Press, 2004, 414 pp

Seely, Bruce E., 2006, “The Beginning of State Highway Administrations: Engineers Take Control,” TR News 245, Jl-Ag, pp. 3-9

Sun, Lena H., 2008, “Travelers Turn to Public Transit,” The Washington Post,” 6/3/08

System Design Concepts, 1975, “The Cooperative Transportation Planning Process in the Portland Metropolitan Area," January

Tattersall, Roger, 2009, “Devotee test-drives hydrogen fuel cars,” Portland Tribune 8/13/09, p. C7

Thompson, Gregory L., 2006, “How Portland's Power Brokers Accommodated the Anti-Highway Movement of the Early 1970s: The Decision to Build Light Rail,” at Business History Conference website, www.thebhc.org/publications/behonline/2005/thompson.pdf

---- , 2007, “Taming the Neighborhood Revolution: Planners, Power Brokers, and the Birth of Neotraditionalism in Portland, Oregon,” Journal of Planning History 6-3, Ag, pp. 14-47 
Tri-County Metropolitan Transit District (Tri-Met), n.d., “A history of public transit in Portland,” at Tri-Met website, http://trimet.org/about/history/transitinportland.htm

Tuhy, John E., 1983, Sam Hill, The Prince of Castle Nowhere, Portland: Timber Press, 305 pp

United Nations, 1992, U.N. Framework Convention on Climate Change (UNFCCC)

University of Oregon, Bureau of Municipal Research and Service, 1957, "Problems of the urban fringe. Prepared for the Legislative Interim Committee on Local Government"

Vanderbilt, Tom, 2008, Traffic: Why We Drive the Way We Do (and What It Says About Us), New York: Knopf, 402 pp

Walth, Brent, 1994, Fire at Eden’s Gate, Portland: OHS Press, 564 pp

Weiner, Edward, 2008, Urban Transportation Planning in the United States: History, Policy and Practice, Springer

Weingroff, Richard F., n.d., “Clearly Vicious as a Matter of Policy: The Fight Against Federal Aid,” Part One, "Unease in the Golden Age,” US Department of Transportation, FHWA, at FHWA website, http://www.fhwa.dot.gov/infrastructure/hwyhist04a.cfm

---- , n.d., “Designating the Urban Interstates,” US Department of Transportation, FHWA, at FHWA website, http://www.fhwa.dot.gov/infrastructure/fairbank.cfm

---- , n.d., “The Genie in the Bottle: The Interstate System and Urban Problems, 1939-1957,” US Department of Transportation, FHWA, at FHWA website, http://www.tfhrc.gov/pubrds/septoct00/urban.htm

---- , n.d., “Addressing the Quiet Crisis: Origins of the National Environmental Policy Act of 1969,” US Department of Transportation, FHWA, at FHWA website, http://www.fhwa.dot.gov/highwayhistory/nepa/index.cfm

Wikipedia, n.d., http://en.wikipedia.org/wiki/Federal-Aid_Highway_Act

Wikipedia, n.d., http://en.wikipedia.org/wiki/Jane_Jacobs

Wikipedia, n.d., http://en.wikipedia.org/wiki/Robert_Moses

\section{TIMELINES}

Bonner, Ernie, PlanPDX.org, 2000, “Riverfront for People,” at PlanPDX website, http://www.pdx.edu/usp/planpdxorg-riverfront-people

Ecotopia.org, n.d., Ecology Hall of Fame, Environmental Movement Timeline, online at http://www.ecotopia.org/ehof/timeline.html

Granlund, Mark, “The History of Transportation in Washington County,” online at http://washtech.co.washington.or.us/funding/history-details.cfm

Oregon Department of Land Conservation and Development, n.d., history of Oregon land use planning, at website http://www.oregon.gov/LCD/history.shtml\#1973_1979

Oregon Department of Transportation (ODOT), n.d., “Oregon on the Move, a history of Oregon’s transportation systems," $164 \mathrm{pp}$ 
Tri-County Metropolitan Transit District (Tri-Met), n.d., “A history of public transit in Portland,” at Tri-Met website, http://trimet.org/about/history/transitinportland.htm

University of California at Davis, n.d., "Important Federal Legislation Relating to Urban Transportation, online at http://www.des.ucdavis.edu/faculty/handy/TTP220/Fed_legislation_06.pdf

\section{BACKGROUND INTERVIEWS}

Beaton, Russell, professor emeritus, Willamette University; former member, Goals Technical Advisory Committee, Oregon Department of Land Conservation and Development, telephone interview with the author, June 2009

Bryant, Robert, Region 4 Manager, Oregon Department of Transportation, telephone interview with the author, July 2009

Burco, Robert, former director, Oregon Department of Transportation, interview with the author, Portland State University, June 2009

Cease, Jane, former Oregon state representative; former director, Department of Motor Vehicles, Oregon Department of Transportation, interview with the author at Cease home, July 2009

Cortright, Robert, transportation planner, Oregon Department of Land Conservation and Development, telephone interviews with the author, June 2009

Edner, Sheldon, financial administrator, US Department of Transportation; former professor, Portland State University, telephone interview with the author, June 2009

Greenfield, Mark, transportation planner and consultant; former staff attorney, One Thousand Friends of Oregon; co-author, Transportation Planning Rule, interview with the author at Greenfield home, July 2009

Johnson, Charles, Robert Straub biographer, telephone conversation with the author, August 2009

Rorabaugh, Thayer, transportation planning director, City of Vancouver, Washington, interview with the author at Vancouver city offices, August 2009

Robinson, Michael, attorney, Perkins Cole LLP, telephone conversation with the author, September 2009

Russell, Peter, senior transportation planner, Deschutes County, telephone interview with the author, March 2009

Shields, Chip, Oregon state senator and former state representative, conversation with the author at Shields district offices, August 2009

Simpson, Michael, transportation advocate, Rocky Mountain Institute, Boulder, Colorado, telephone interview with the author, July 2009

Sinks, James, former reporter, Bend Bulletin, , telephone conversation with the author, June 2009

Stacey, Robert, outgoing director, One Thousand Friends of Oregon, interview with the author at Friends offices, July 2009 


\section{BACKGROUND REFERENCES}

Adler, Sy, 1994, “The Oregon Approach to Integrating Transportation and Land Use Planning,” in Carl Abbott, Deborah Howe and Sy Adler, eds., Planning the Oregon Way: A Twenty-Year Evaluation, Corvallis: OSU Press, pp. 121-146

Adler, Sy and Jennifer Dill, 2004, “The Evolution of Transportation Planning in the Portland Metropolitan Area,” in Connie P. Ozawa, ed., The Portland Edge: Challenges and Successes in Growing Communities, Washington, DC: Island Press, 321 pp

American Dream Coalition, n.d., “The High-Capacity Transit Myth,” at ADC website, www.americandreamcoalition.org/transit/railmyths.html

Bates, David, 2009, “Enviros take aim at bypass,” McMinnville News Register, 6/12/09

Batterman, Joel M., 2008, “The Land Use- Transportation- Climate Change Connection,” Portland: 1000 Friends of Oregon, 38 pp

Blakely, Joe R., 2006, Lifting Oregon Out of the Mud: Building the Oregon Coast Highway, Wallowa, OR: Bear Creek Press, 65 pp

Bohard, Jeri, 2008, memorandum from administrator, Transportation Development Division, Oregon Department of Transportation, to Oregon Transportation Commission, dated 8/14/08, re: Transportation Planning Rule and local plans

Bragdon, David, 2006, Opening Remarks, Regional Transportation Workshop, April 20, 2006, online at http://portlandtransport.com/archives/2006/04/a_history_lesso.html

Buel, Ronald A., 2006, “Let’s put the East Bank freeway in a tunnel,” guest column, Blue Oregon website, http://www.blueoregon.com/2006/11/lets_put_the_ea.html (11/16)

Burco, Robert A. and Clark D. Henderson, 1971, “Systems Innovations for Urban Transportation,” Transportation Engineering Journal (May) pp. 205-226

Cambridge Systematics, 2009, Final Technical Memorandum on freight regulations, presented to Oregon Freight Plan Steering Committee, 7/22/09

Cortright, Robert, Richard Whitman and Jeffrey Weber, 2009, “Planning for Climate Change,” memorandum to the Oregon Land Conservation and Development Commission for June 4-5 meeting

Cotugno, Andrew and Richard Benner, n.d., "Regional Growth Management in the Portland, Oregon Metropolitan Area," Metro, 13 pp

Crawford, J.H., 1977, Carfree Cities, Utrecht: International Books, 323 pp

Dueker, Kenneth, Sheldon Edner and William A. Rabiega, 1987, “Transportation Planning in the Portland Metropolitan Area,” in Larry W. Price, ed., Portland's Changing Landscape, Occasional Papers, Department of Geography, Portland Sate University, pp. 136-143

Freemark, Yonah, 2009, “What's Wrong with SAFETEA-LU - and Why the Next Bill Must Be Better,” online at http://la.streetsblog.org/2009/04/28/what's-wrong-with-safetea-lu-—-and-why-the-next-bill-must-be-better/

Green Car Congress, 2009, "Study Finds Bioelectricity Better Option Than Liquid Biofuels for Transportation Output and GHG Emissions,” online at http://www.greencarcongress.com/2009/05/study-finds-bioelectricitybetter-option-than-liquid-biofuels-for-transportation-output-and-ghg-emis.html 
Grillo, Phillip E., 2004, "New Transportation Hurdle Must Be Cleared if Land Use Amendments are Proposed," regarding Jaqua decision, at http://www.millernash.com/showarticle.aspx?Show=801

Jacobson, Mark Z. and Mark A. Delucchi, 2009 “A Path to Sustainable Energy by 2030,” Scientific American (No), pp 58-64

Knack, Ruth Eckdish, 2007, “Land Use and Transportation - You Can’t Have One Without the Other: An interview with [Terry Moore,] co-author of a new PAS report,” Planning, May, pp. 34-37

Leonard, H. Jeffrey, 1983, Managing Oregon's Growth: The Politics of Development Planning, Washington, DC: The Conservation Foundation, 159 pp

Lincoln Institute of Land Policy, 2009, "First major evaluation of smart growth policies finds modest gains for states in fight against sprawl," press release, 5/28/09, for "Smart Growth Policies: An Evaluation of Programs and Outcomes"

Lovins, Amory, 2005, “We must win the oil endgame,” TED online video posted at http://www.ted.com/index.php/talks/amory_lovins_on_winning_the_oil_endgame.html

Lynch, Michael, 2009, “’Peak Oil’ Is a Waste of Energy,” The New York Times Op-Ed, 8/25/09

McFadden, Christine, 2009, “Zipcar helps boost city’s low-car diet,” The Portland Tribune, 9/10/09, C1

Metro, 1981, “The Portland Transportation Program - A Regional Partnership That Works,” 6 pp

---- 2008, council hearing on Columbia River Crossing, 6/5/08 (notes and ephemera)

---- 2009, “2035 Regional Transportation Plan, public review draft,” 9/15/09

---- 2009, council work session on Regional High Capacity Transit System, 5/12/09 (notes and ephemera)

---- 2009, "Making the Greatest Place - Strategies for a sustainable and prosperous region: A report from Metro's Chief Operating Officer," 9/15/09

---- 2009, “State of the Centers: Investing in Our Communities,” 01/09, 103 pp

Moore, Michael, 2009, “Goodbye, GM,” open letter circulated online

Moore, Terry and Paul Thorsnes, 1994, The Transportation/Land Use Connection, Chicago: American Planning Association, $137 \mathrm{pp}$

Morris, Joseph R., 2006, “The Fuel Tax and Alternatives for Transportation Funding,” TRB Special Report, TR News Jl-Ag, pp. 20-21

Mortensen, Eric, 2009, “New to Town? Squeeze In,” The Oregonian, 9/16/09, p. A1

Motavelli, Jim, 2001, Breaking Gridlock: Moving Toward Transportation That Works, San Francisco: Sierra Club, $306 \mathrm{pp}$

National Research Council, National Academy of Sciences, 2009, "Driving and the Built Environment: The Effects of Compact Development on Motorized Travel, Energy Use, and CO2 Emissions - Special Report 298,” September

NewWest.Net, 2009, “Western Rail Network Key to Regional Sustainability,” at Sustainability Blog, 9/17/09 
One Thousand Friends of Oregon, 1992, "LUTRAQ Final Report"

Oregon Business Plan Leadership Summit, 2007, three-disk DVD set (12/3/07)

Oregon Court of Appeals, 1998, Department of Transportation v Douglas County, Judicial Review from Land Use Board of Appeals

Oregon Department of Land Conservation and Development, 1979-81, correspondence concerning Woodburn comprehensive plan revisions

---- 1982, staff report on Douglas County comprehensive plan, dated 4/29/82

Oregon Department of Transportation, 1981, “Airport Compatibility Guidelines”

---- 1987, Highway Compatibility Study

---- 1996, “Agency History,” at DLCD website, http://bluebook.state.or.us/state/executive/Transportation_Dept/transportation_dept_history.htm

---- 1999, “Freight Moves the Economy,” Planning Section, Transportation Development Division, online at http://www.oregon.gov/ODOT/TD/TP/FME.shtml\#Freight_Moves_the_Economy

---- 2009, “Oregon Transportation and Growth Management Program 2007-2009 Biennial Report,” January, 19 pp

---- 2009, “ODOT Intercity Passenger Rail Study, June 2009 Draft”

Oregon Environmental Council, 2008, “Cutting Carbs: A Professional Development Workshop for Transportation Professionals,” Doubletree Lloyd Center, 12/3/08 (notes and ephemera)

Oregon Freight Advisory Committee, 2004, “Oregon Freight Advisory Committee Recommendations: High Priority Freight Mobility Projects,” presented to Oregon Transportation Commission, 4/28

Oregon Global Warming Commission, 2009, Report to the Legislature, 55 pp

Redden, Jim, 2009, “Emission goals prove elusive,” The Portland Tribune, 9/17/09

---- 2009, “35 Years in Training: Born of a '70s freeway rebellion, I-205 Green Line finally arrives,” The Portland Tribune, 9/10/09

Rivera, Dylan, 2009, “Density and mass transit can fight global warming, study says,” The Oregonian, 9/4/09, posted at blog.oregonlive.com (with 33 pages of responses)

---- 2009, “MAX: More than the sum of its parts,” The Oregonian, 9/11/09

Parsons Brinckerhoff, 2009, "Document Review and Analysis of Economic Forecasts," and "Relationship of Freight Transportation to Economic Development," reports presented to the Oregon Freight Plan Steering Committee, 7/22/09,

Portland State University, 2008, PSU Economic Development Summit, University Place, Portland State University, 5/28/08 (notes and ephemera)

Rich, Frank, 2009, “Is Obama Punking Us?” New York Times, 8/9/09

Royer, Robert E, Planning Engineer, Retired (Oregon Department of Transportation), n.d., “Oregon: from Highways to Transportation: My Recollections” 
Scientific American, editors, 2009, “The Future of Cars,” Nov issue, pp. 89-92

Sullivan, Edward J., 1998, "Remarks to University of Oregon symposium marking the twenty-fifth anniversary of S.B. 100"

Sunriver, community of, 1982, comprehensive plan submittal, final draft dated 11/3/82

Transportation for America, 2009, “The Route to Reform: Blueprint for a $21^{\text {st }}$ Century Federal Transportation Program,” Washington, DC, 97 pp

Transportation Vision Committee, 2008, Report to Governor Ted Kulongoski, November

Waddell, Paul, 2001, “Toward a Behavioral Integration of Land Use and Transportation Modeling,” paper presented to $9^{\text {th }}$ International Association for Travel Behavior Research Conference, Queensland, Australia, 1/29

Washington Transportation Policy Institute (with the Washington State ISTEA Steering Committee, Dye Management Group, Cambridge Systematics et al), n.d. (1991), ISTEA Handbook, 53 pp

West Eugene Collaborative, 2009, “A New Vision for West Eugene,” 03/09

Wikipedia, n.d., http://en.wikipedia.org/wiki/Great_American_streetcar_scandal

Wiley, Allison, Oregon Department of Transportation, 2009, presentation as part of OTREC seminar series (Winter term) on social marketing of alternative transportation choices 



\section{AOTREC \\ OREGON TRANSPORTATION RESEARCH \\ AND EDUCATION CONSORTIUM}

\section{P.O. Box 751}

Portland, OR 97207

OTREC is dedicated to stimulating and conducting collaborative multi-disciplinary research on multi-modal surface transportation issues, educating a diverse array of current practitioners and future leaders in the transportation field, and encouraging implementation of relevant research results. 